\title{
Đánh giá thành tựu 30 năm đổi mới và định vị kinh tế Việt Nam
}

\author{
PGS.TS. Trần Đình Thiên ${ }^{1}$ \\ ThS. Chu Minh Hội ${ }^{2}$
}

Việt Nam có những nền tảng đề trở thành một quốc gia thịnh vượng. Yếu tố bảo đảm thành công cho Việt Nam - như kinh nghiệm 30 năm công cuộc đổi mới chỉ ra - phụ thuộc quyết định vào việc lựa chọn con đường phát triển.

\section{Thành tựu phát triển kinh tế - xã hội của 30 năm đổi mới}

\section{a. Tăng trưởng kinh tế - giảm nghèo - công bằng xã hội}

Cải cách kinh tế của Việt Nam là một tiến trình phức tạp, không bằng phẳng và đầy cam go, được phản ánh trong sự tiến hóa tư duy phát triển qua các giai đoạn.

Phát triển nền kinh tế nhiều thành phần, mở cửa là thông điệp chính của chương trình Đổi mới năm 1986.

Đến giai đoạn 1990-2000, phát triển kinh tế thị trường có sự quản lý của nhà nước là thông điệp thay thế.

Từ năm 2001 đến nay, đường lối phát triển nền kinh tế thị trường định hướng xã hội chủ nghĩađược khẳng định.

Không nghi ngờ gì rằng thành tựu quan trọng bậc nhấtcủa Đổi mới là việc chuyển nền kinh tế kế hoạch hóa tập trung quan liêu bao cấp dựa trên nền tảng nền kinh tếnông nghiệp- nông dân cổ truyền sang kinh tếthị trường, nhờ đó, đất nước thoát khỏi phương thức phát triểnlạc hậu, biến quá trìnhnày thành xu hướng không thể đảo ngược. Đây là kết quả của sự liên tục đồi mới tư duy phát triển, chuyển hóa sức mạnh của tư duy phát triển mới, phù hợp với xu hướng chung của thế giới,thành các thành tựu kinh tếhiện thực, cụ thể, biểu hiện ở mức tăng trưởng kinh tế cao, tỷ lệ hộ nghèo giảm mạn, cơ cấu kinh tếchuyển dịch theo hướng tích cực, ngoại thươngphát triển, thu hút nhiều FDI và ODA, chủ động và tích cực mở cửa, hội nhập kinh tế thế giới.

Nhưng mặt khác, đó cũng là quá trình vật lộn với khó khăn, gian khổ để tiến lên, là cuộc đấu tranh cam go giữa lực lượng cải cách và các yếu tố bảo thủ.

Trên thực tế, ba năm sau đổi mới, kinh tế Việt Nam vẫn chưa thoát khỏi tình trạng khủng hoảng. Lạm phát các năm 1987 và 1988 vẫn ở mức 3 con số $(323,1 \%$ và $393 \%)$. Nhưng kể từ năm 1989, nhiều chuyển biến thực tế quan trọng đã diễn ra. Nhà nước phân quyền sử dụng và chuyển giao quyền sử dụng đất cho từng hộ gia đìnhtheo Nghị quyêt 10

\footnotetext{
${ }^{1}$ Viện truơong Viện Kinh tế Việt Nam - Viện Hàn lâm Khoa học Xã hội Việt Nam

${ }^{2}$ Chuyên gia Kinh tế Vĩ mô - Phòng Kinh tế Vĩ mô và Thể chế - Viện Kinh tế Việt Nam
} 
(Khoán 10), xóa bỏ độc quyền nhà nước trong hoạt động ngoại thương (cuối 1988). Đến năm 1989,chế độ tem phiếu và kiểm soát giá cả đượcbãi bỏ.

1989 là năm đầu tiên Việt Nam không những có đủ lương thực đáp ứng nhu cầu trong nước, mà còn xuất khẩu 1,4 triệu tấn gạo. Thành tựu này phản ánh sức mạnh giải phóng nội lực của cải cách đối với sản xuất nông nghiệp.

Từ giữa năm 1989, lạm phát phi mã gần như ngừng hẳn.Tình trạng rối loạn trong phân phối, lưu thông hàng hóa cơ bản chấm dứt, môi trường vĩ mô bắt đầu ổn định.

Từnăm 1990, nhiều chính sách mới trở thành đòn bẩy đưa đất nước bước vào một giai đoạn mới, ổn định hơn.Sự ra đời của Luật Công ty, Luật Doanh nghiệp tư nhân, Luật Thuế doanh thu,việccông nhận kinh tế tư nhân trong Hiến pháp năm 1992 đóng vai trò là những dấu mốc thay đổi thể chế nền tảng theo hướng thị trường.

Tăng trưởng kinh tế trong phần lớn thập niên 1990 đạt mức 8-9\%/năm. Thành tựu này có được là nhờ năng lực sản xuất và hiệu quả đầu tư được cải thiện dưới tác động của cải cách kinh tế.

Tronggiai đoạn1997-1999, tăng trưởng kinh tế của Việt Nam bị sụt giảm mạnh tốc độ tăng trưởng, một phần do các vấn đềcơ cấu bắt đầu bộc lộ, một phần do ảnh hưởng từ khủng hoảng tài chính châu Á.

Tuy nhiên, phải đếncuộc khủng hoảng tài chính toàn cầu 2008-2009, sau giai đoạn khôi phục tăng trưởng khá ngoạn mục dưới tác động trực tiếp mạnh mẽ của việc ký Hiệp định thương mại song phương Việt Nam- Hoa kỳ, khi nền kinh tếViệt Nam bắt đầu thử thách năng lực hội nhậpquốc tế với phép thử gia nhập WTO (2007), tốc độ trongkinh tế lại suy giảm mạnh;và đặc biệt, những vấn đề cấu trúccủa nền kinh tế ngày càng trở nên nghiêm trọng.

Như vậy, sự thăng trầm kinh tế của nền kinh tếđổi mới bộc lộ rõ, mặc dù xét cảchặng đường dài, những thành tựu phát triển kinh tế của Việt Nam trong suốt 30 năm qua là hết sức ấn tượng. Tính chung cho giai đoạn 1990-2010, tăng trưởng GDP của Việt Nam đạt bình quân 7,3\% (IMF, 2011), chỉ thấp hơn mức tăng trưởng của Trung Quốc.

Từ một nước nông nghiệp thuộc nhóm nghèo nhất thế giới, với mức GDP bình quân đầu người chỉ 98 USD, Việt Nam đã gia nhập nhóm các quốc gia có thu nhập trung bình thấp năm 2011. GDP bình quân đầu người năm 2013 đạt mức 1.910 USD (Dữ liệu WDI), bằng gần 7 lần năm 2000 và 9,5 lần năm 1986.

Điểm nổi bật trong thành tựutăng trưởngcủa Việt Nam không chỉ nằm ở tốc độ tăng trưởng cao, mà cả ở tính bao trùm (inclusive). Tỷ lệ nghèo từ mức trên $85 \%$ dân số (theo chuẩn nghèo 2USD/người, ngày) của năm 1993 giảm xuống còn khoảng 13\% năm 2013; tình trạng nghèo cùng cực (theo chuẩn 1,25 US\$/ngày) gần như biến mất, trong khi bất bình đẳng tăng không đáng kể và vẫn nằm trong mức trung bình của thế giới (Hình 1)

\section{Hình 1: Tăng trưởng GDP, tỷ lệ nghèo và hệ số Gini của Việt Nam (1986-2013)}




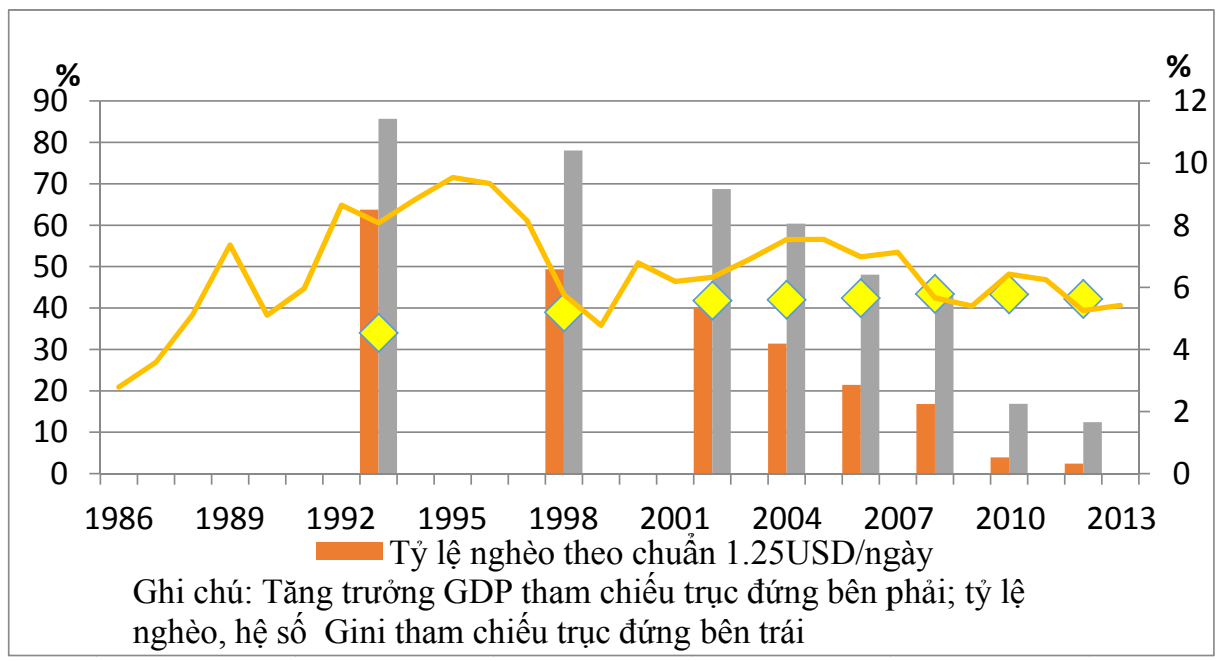
Gini).

Nguồn: xủ lý tì dũ liệu WDI (tăng trương và tỷ lệnghèo), TCTK (Hệ số

\section{b. Thành tựu đổi mới cấu trúc ngành kinh tế}

Tỷ trọng khu vực nôngnghiệp trong cơ cấu GDP giảm nhanh, từ 47\% năm 1988 còn $18-20 \%$ từ năm 2000 đến nay.Ngược lại, tỷ trọng công nghiệp tăng từ khoảng $23 \%$ vào cuối những năm 1980 lên gần 40\% hiện nay.Tỷ trọng khu vực dịch vụ cũng tăng lên, nhưng mức tăng nhỏ và đóng góp của khu vực này trong cơ cấu GDP khá ổn định.

Về cơ cấu lao động, số lao động nông nghiệp chiếm hơn $2 / 3$ tổng số giai đoạn 1986-1990, đã giảm đều đặn xuống còn khoảng 46\% vào năm 2013 (Dũ̃ liệu WDI). Tỷ trọng lao động công nghiệp tăng tương ứng: mỗi năm có thêm 1 điểm phần trăm người lao động chuyển ra khỏi khu vực nông nghiệp và được khu vực công nghiệp hấp thụ.

\section{Hình 2: Cơ cấu GDP và tỷ trọng khu vực chế tạo trong GDP Việt Nam (1986-2013)}

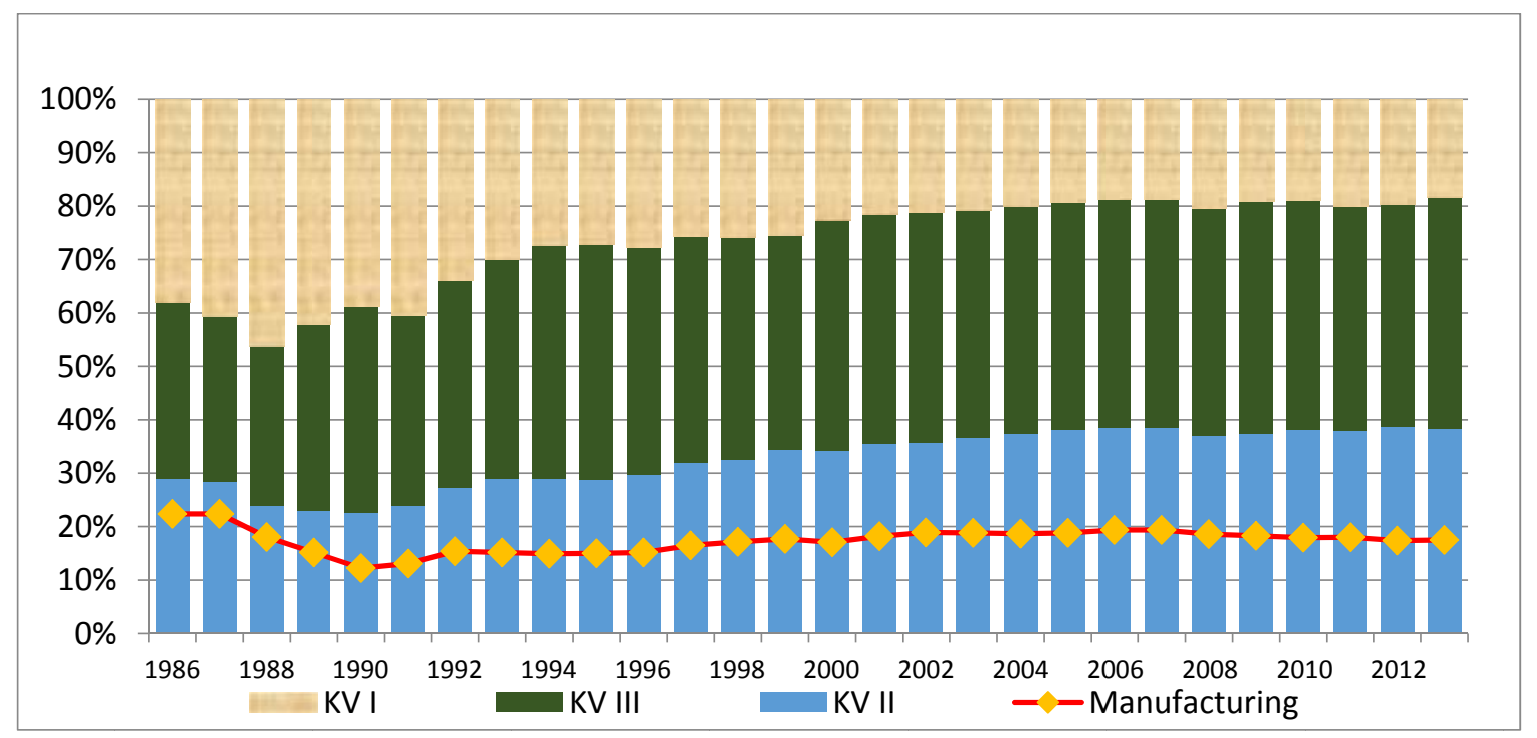

Nguồn: Xủ lý tì dĩu liệu WDI. 


\section{c. Thành tựu mở cửa - hội nhập}

Trước Đổi mới, Việt Nam đã có quan hệ ngoại thương với thế giới, nhưng chủ yếu là với khối XHCN.Năm 1986, Việt Nam bắt đầu mở cửa ra với cả thế giới.Luật đầu tư nước ngoài năm 1987 khơi nguồn cho dòng vốn đầu tư và thương mại quốc tế.

Năm 1993, Việt Nam bình thường hóa quan hệ với 3 định chế tài chính quốc tế lớn là $\mathrm{WB}, \mathrm{IMF}$ và $\mathrm{ADB}$.

Năm 1994, Việt Nam thoát khỏi cấm vận, thiết lập quan hệ ngoại giao bình thường với Hoa Kỳ

Ngày 28/07/1995, Việt Nam gia nhập ASEAN.

Năm 1997, Việt Nam tham gia Diễn đàn Hợp tác Kinh tế Châu Á - Thái Bình Dương (APEC).

Hiệp định Thương mại song phương Việt Nam - Hoa Kỳ (ký tháng 7/2000, có hiệu lực từ tháng 12/2001) là bước tiến tiếp theo trong tiến trình hội nhập.

Năm 2007, nền kinh tế tiến một bước lớn trong tiến trình hội nhậpquốc tếkhigia nhập WTO.

Cuối năm 2014, Việt Nam hoàn thành đàm phán Hiệp định thương mại tự do với Hàn Quốc, với Liên minh Hải quan Nga-Belarusia-Kazakhstan. Sang năm 2015, Việt Nam kết thúc đàm phán TPP và Hiệp định thương mại tự do với EU.

Hội nhập quốc tế mang lại nhiều lợi ích cho phát triển kinh tế của Việt Nam, trước hết là ở việc giải phóng các nguồn lực và hình thành tư duy phát triển kinh tế mới. Các cam kết hội nhập đòi hỏi Việt Nam phải dần xóa bỏ cơ chế bảo hộ, trợ cấp, minh bạch hóa hoạt động kinh doanh và các cơ chế chính sách, thúc đẩy xây dựng các chuẩn mực về tổ chức sản xuất, quản lý và văn hóa kinh doanh.Hội nhập cũng thúc đẩy việc chuyển nhượng vốn xuyên quốc gia, chuyển nhượng công nghệ, phương pháp tiếp cận thị trường và gia tăng năng lực cạnh tranh quốc gia do khu vực FDI tạo ra.

Nếu coi các sản phẩm có kim ngạch xuất khẩu trên 1 tỷ USD là sản phẩm chủ lực của Việt Nam, thì năm 2001 cả nước mới có 4 sản phẩm chủ lực.Năm 2010, số sản phẩm chủ lực đã tăng 5 lần. Đến năm 2010, số sản phẩm kim ngạch xuất khẩu trên 1 tỷ USD tăng 5 lần, trong số này,có các nhóm sản phẩm công nghiệp - công nghệ cao. Năm 2014, cả nước có 7 nhóm sản phẩm có kim ngạch xuất khẩu trên 5 tỷ USD.

Tuy vậy, tăng trưởng kinh tế về dài hạn không thể dựa vào các sản phẩm có trình độ công nghiệp thấp hoặc trung bình và thâm dụng lao động. Thực trạng này cũng là bài toán Việt Nam cần lựa chọn giải pháp mới trong giai đoạn tiếp theo.

Một trong những yếu tố thành công cho tăng trưởng kinh tế Việt Nam trongđổi mớilà thu hút FDI. Dòng vốn FDI bắt đầu vào Việt Nam sau khi Luật đầu tư nước ngoài được ban hành năm 1987. Thị trường mở cửa và môi trường kinh doanh đượccải thiện tạo sức hút FDI mạnh mẽ.Tuy nhiên, vốn FDI chỉ thực sự trở thành một sức mạnh đáng kể từ năm 1991.Đến năm 1994, quy mô vốn FDI đã tương đương 10\% GDP cả nước và đóng góp đáng kể vào thành tích tăng trưởng cao trong những năm trước khủng hoàng tài chính 
châu Á (Hình 3). Trong làn sóng FDI đầu tiên, thời điểm đánh dấu là khiViệt Nam gia nhập ASEAN năm 1995 và FDI đạt đỉnh sau đó 1 năm. Điều tương tự diễn ra khi Việt Nam gia nhập WTO năm 2007 và FDI đăng ký đạt mức cao nhất vào năm 2008.

\section{Hình 3: Vốn FDI đăng ký và giải ngân giai đoạn 1986-2014}

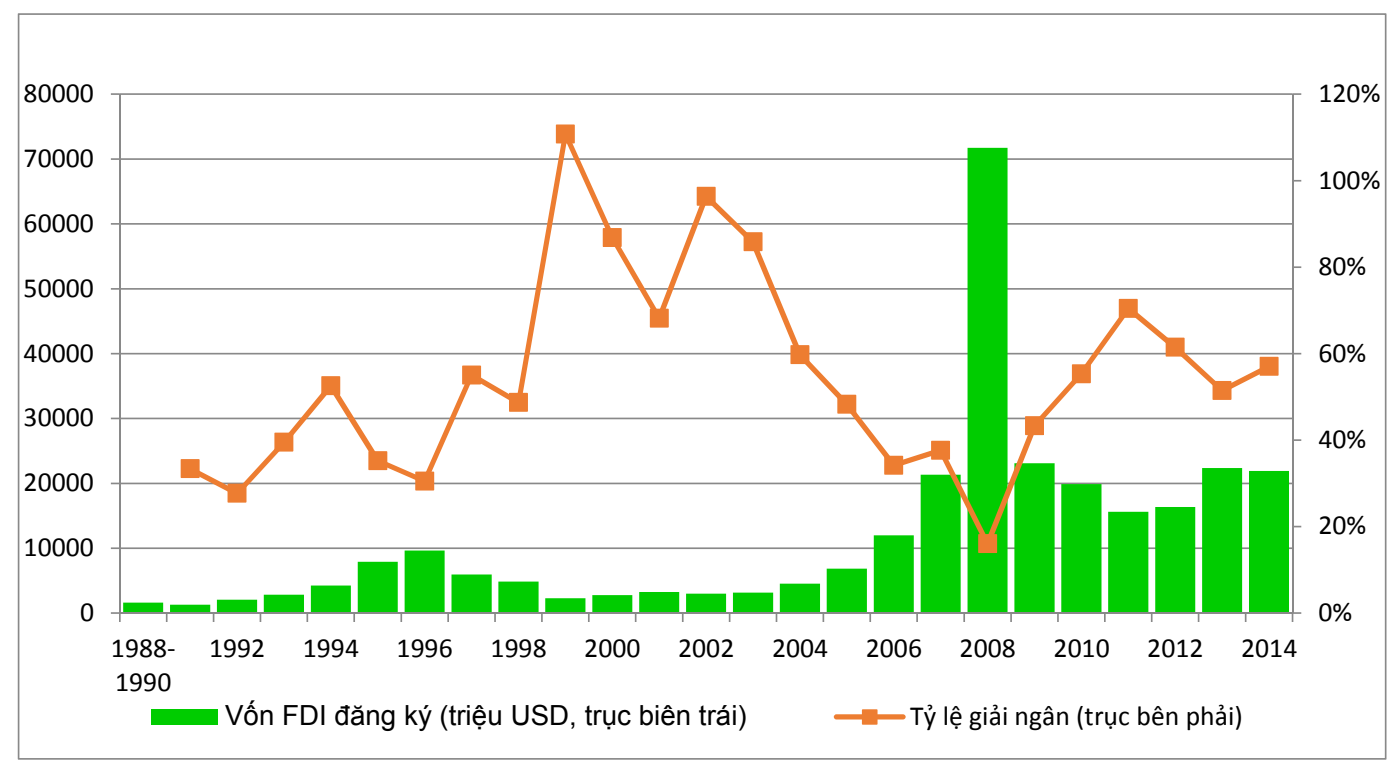

Nguồn: Tổng cuc Thống kê

Đến giữa thập kỷ 1990, doanh nghiệp FDI đóng góp 1/4 tổng giá trị sản xuất công nghiệp và hơn $6 \%$ GDP. Mười năm sau, các tỷ trọng tương ứng là43,8\% và $15,99 \%$ (Bảng 1). Khu vực FDI đã vượt lên trên khu vực nội địa về giá trị sản xuất công nghiệp từ năm 2014,vượt lên về kim ngạch xuất khẩu từ năm 2004 và hiện đã chiếm tới gần $70 \%$ tổng kim ngạch xuất khẩu hàng hóa của cả nền kinh tế.

\section{Bảng 1: Đóng góp của khu vụ̣c FDI}

\begin{tabular}{|c|c|c|c|}
\hline Năm & Tỷ trọng GDP & Tỷ trọng GTSX công nghiệp & Tỷ trọng xuất khẩu \\
\hline 1995 & 6,3 & 25,1 & $17,1^{3}$ \\
\hline 1997 & 9,07 & 29 & \multirow{2}{*}{31,5} \\
\hline 2000 & 13,28 & 41,3 & \\
\hline 2001 & 13,75 & 41,5 & \multirow{2}{*}{42,8} \\
\hline 2005 & 15,99 & 43,81 & \\
\hline 2006 & 16,98 & 44,38 & \multirow{2}{*}{55} \\
\hline 2009 & 18,33 & 43,15 & \\
\hline 2010 & 17,69 & 42 & 54,1 \\
\hline 2012 & 18,09 & 47,2 & 64 \\
\hline 2013 & 19,55 & 50,1 & 66,9 \\
\hline
\end{tabular}

Nguồn: Niên giám thống kê và tổng hợp tù nhiều nguồn

${ }^{3}$ Tình chung giai đoạn 1991-1995 
Cũng phải thấy rằng tỷ lệ vốn FDI thực hiện trong nhiều năm là không cao, cũng không có xu hướng tăng tương ứng với lượng vốn đăng ký.Điều này một mặt có nguyên nhân khách quan là những biến động kinh tế thế giới, nhưng mặt khác cũng phản ánh một thực tế là vẫn còn những trở ngại trong môi trường kinh doanh của Việt Nam.Sự suy giảm dòng vốn FDI sau năm 1996đã được dự báo và chỉ ra nguyên nhân là do môi trường đầu tư chậm được cải thiện,những hạn chế của hệ thống quản lýkinh tế - hành chính dần bộc lộ (WB, 1997).Ở xu hướng suy giảm FDI sau năm 2008, tăng trưởng kinh tế nhanh được hỗ trợ bởi sự mở rộng tín dụng và cung tiền quá nóng trongnhững năm trước đó đã gây ra những trục trặc cấu trúc làm cho môi trường vĩ mô không ổn định. Điều này làm yếu khả năng hấp thụ vốn FDI.

Điều tích cực nằm ở tính ổn định của giá trị giải ngân FDI, xung quanh mức 11-12 tỷ USD mỗi năm tronggiai đoạn từ năm 2008 đến nay.

\section{d. Những thành tựu khác}

Ngoài những thành tựu ấn tượng về tăng trưởng kinh tế, cấu trúc kinh tế cũng như trong giảm nghèo, công bằng xã hội như trên đây, chặng đường 30 năm Đổi mới cũng chứng kiến nhiều thành tựu lớn của Việt Nam trong các lĩnh vực khác.Năm 2012, Việt Nam tham gia Chương trình đánh giá học sinh quốc tế (PISA) do OECD thực hiện với kết quả hết sức ấn tượng: Việt Nam xếp thứ 17/65 quốc gia được khảo sát về năng lực toán học(đạt 511 điểm), cao hơn mức bình quân 494 của các nước $\mathrm{OECD}$, thậm chí cao hơn một số quốc gia phát triển khác như Anh, Pháp, Ý, Hoa Kỳ hay Israel.Thực tế này cho thấy, tiềm năng trí tuệ của người Việt Nam là rất to lớn.Nhưng điều đó cũng bộc lộ rõ thứ quốc gia còn thiếu là cách thức phát triển và sử dụng tiềm năng đó.

\section{Hình 4: Diễn tiến bao phủ y tế toàn dân ở Việt Nam (1989-2020)}

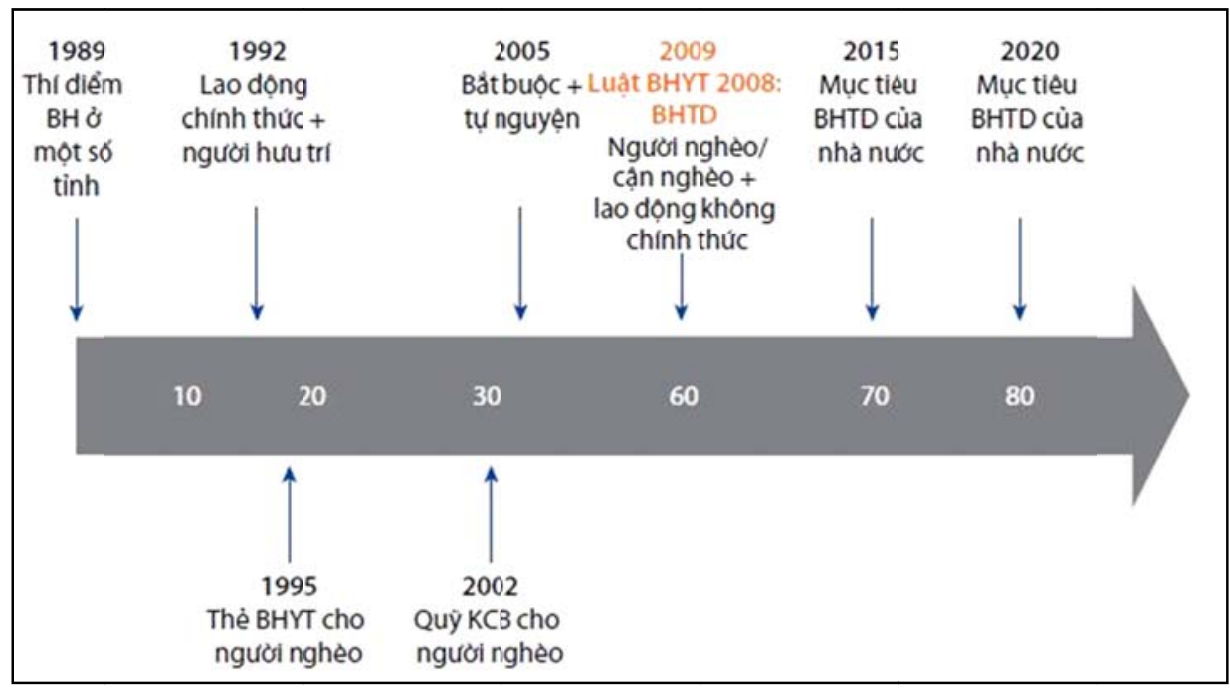

Nguồn: WB (2014). Tiến tới bảo hiểm y tế toàn dân.

Việt Nam hoàn thành sớm Mục tiêu Thiên niên kỷ (MDG) về giảm nghèo đói. Mục tiêu MDG giảm một nửa số người có mức thu nhập dưới 1 USD (giá PPP)/ngày trong giai đoạn 1990-2015 đã được hoàn thành năm 2008, khi tỷ lệ này giảm xuống còn 
4,1\% từ mức 39,9\% năm 1993. Từ khoảng 30\% dân số nông thôn được sử dụng nước sạch vào năm 1990, sau hai thập kỷ tỷ lệ này lên tới $83 \%$.

Ở mục tiêu phổ cập giáo dục, tỷ lệ nhập học tiểu học năm 2009 đạt 95,5\%, tỷ lệ hoàn thành tiểu học $88,2 \%$ và tỷ lệ dân sốtrong độ tuổi $15-24$ biết đọc, viết là $97,1 \%$.

Bảng 2: Tỷ lệ người khám chữa bệnh nội, ngoại trú có bảo hiểm y tế hoặc sổ/thẻ khám chữa bệnh miễn phí (\%)

\begin{tabular}{|c|c|c|c|c|c|c|}
\hline Năm & Cả nước & Nhóm 1 & Nhóm 2 & Nhóm 3 & Nhóm 4 & Nhóm 5 \\
\hline 2004 & 37.4 & 44.1 & 32.3 & 31.7 & 35.3 & 43.3 \\
\hline 2006 & 57.4 & 71 & 52.9 & 49 & 53.5 & 60.9 \\
\hline 2008 & 61 & 72 & 55.7 & 53 & 57.4 & 66.5 \\
\hline 2010 & 66.7 & 74.1 & 61.2 & 60.4 & 66.6 & 70.9 \\
\hline 2012 & 72.1 & 81.5 & 67.7 & 66.6 & 69.4 & 75.3 \\
\hline
\end{tabular}

Nguồn: Kết quả Khảo sát mức sống dân cu 2012 - TCTK

Trong lĩnh vực y tế, tỷ lệ dân cư được bảo hiểm y tế tăng nhanh trong mấy năm gần đây, đạt $60 \%$ vào năm 2010 (dữ liệu WB), và 68\% năm 2012 [UN ở Việt Nam,2014 Báo cáo Thường niên 2013, tr. 54]. Bước tiến là rất đáng kể nếu nhìn lại giai đoạn1990 2005 ,khi cả nước chỉ có $20-30 \%$ số người nằm trongvùng bao phủbảo hiểm y tế (Hình 8 ). Nhiều khả năng Việt Nam sẽ đạt mục tiêu quốc gia bảo hiểm toàn dân ở mức $70 \%$ vào năm 2015 , và đạt $80 \%$ sau đó5 năm. Trong số những người khám chữa bệnh, tỷ lệ người được bảo hiểm y tế hoặc có sổ/thẻ khám chữa bệnh miễn phí đã tăng từ 37,4\% lên 72,1\% trong giai đoạn 2004-2012 (Bảng 2). Đáng chú ý là tỷ lệ này của nhóm 1 (nhóm 20\% người có thu nhập thấp nhất) cao hơn các nhóm khác và đạt hơn 70\% từ năm 2006 .

Hình 5: Chỉ số Phát triển Con người Việt Nam (1980-2013)

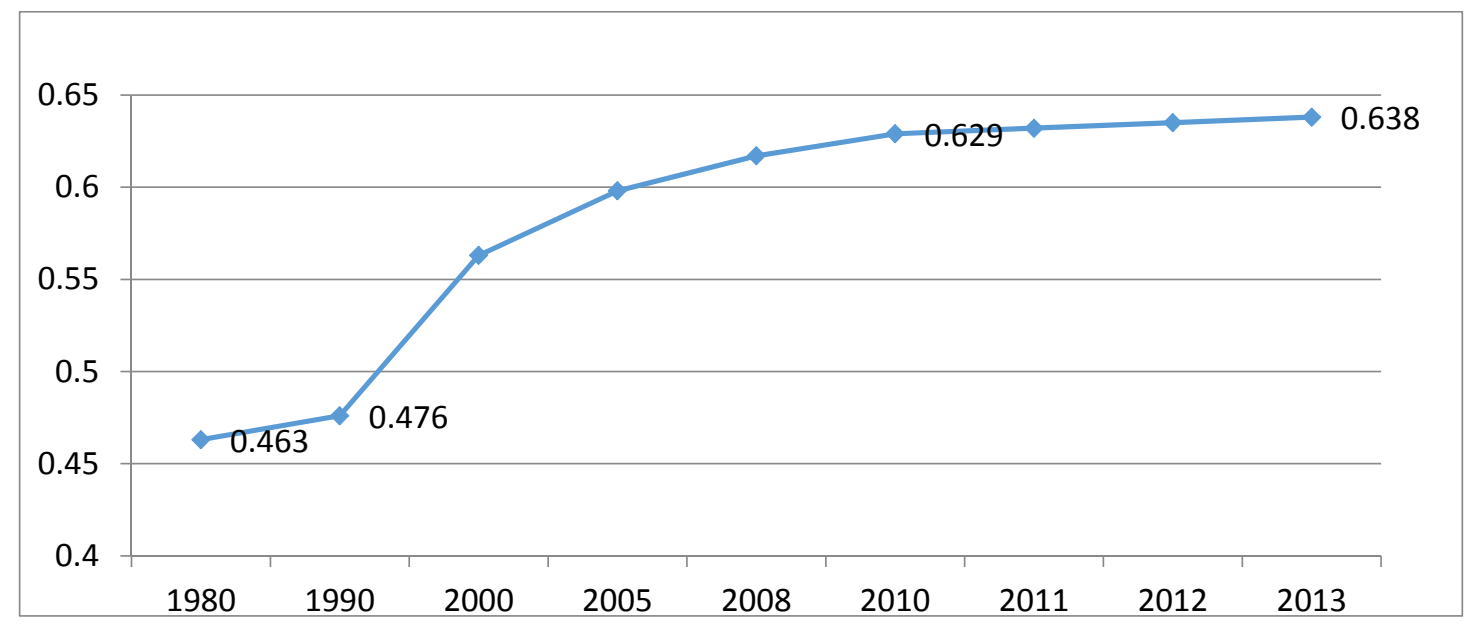

Nguồn: Human Development Reports - UNDP.

Tăng trưởng liên tục trong Chỉ số Phát triển Con người (HDI)của Việt Nam là một bằng chứng khác cho thấy những thành tựu của quá trình cải cách. Tăng trưởng thu nhập 
cùng những thành tựu trong tạo môi trường bình đẳng trong giáo dục, chăm sóc y tế được chuyển hóa đầy đủ trong sự tăng trưởng của chỉ số HDI. Chỉ số này đã tăng liên tục từ mức 0,463 vào năm 1980 lên mức 0,638 vào năm 2013, trong đó, giai đoạn 1990-2000 có tốc độ tăng trưởng cao hơn cả (Hình 5).

\section{Nhiều thách thức lớn}

Thành tựu phát triển đã đạt được không đảm bảo rằng Việt Nam sẽ tiếp tục thành công trong những giai đoạn tiếp theo. Có thể chỉ ra một loạt các vấn đề cấu trúc đang cản trở khả năng phát triển đột phá của đất nước. Đó là: Sự méo mó của thị trường gây ra bởi sự độc quyền và đặc quyền của $\mathrm{DNNN}$, sự yếu kém của hệ thống tài chính và những nút thắt thể chế, kỹ năng thấp của nguồn nhân lực, chi phí vận tải đắt đỏ, tiếp cận tín dụng, năng lượngvà đất đai khó khăn. Trong bối cảnh thế giới đang trải qua một thời kỳ hết sức phức tạp, cùng với đó là các vấn đề xã hội khác như môi trường xuống cấp, biến đổi khí hậu, dân số già hóa cần được giải quyết, thì việc Việt Nam cam kết hội nhập ởđẳng cấp cao nhất đang đặt ra những thách thức to lớn. Việc lựa chọn sai mô hình phát triển có thể đưa đất nước đi ngược lại tiến trình phát triển và sẽ tụt hậu phát triểnngày càng xa hơn. Các cơ sở cho tăng trưởng trong dài hạn là không bền vững.

\section{a. Chất lượng tăng trưởng có xu hướng giảm mạnh}

Thể hiện qua sự suy giảm đóng góp của TFP trong tăng trưởng GDP và tăng lên của hệ số ICOR, và môi trường kinh tế vĩ mô thiếu ổn định biểu hiện ở biến động lạm phát. Trong giai đoạn 2007-2012, TFP chỉ đóng góp khoảng 6,44\%, giảm mạnh so với mức 22,6\% của giai đoạn 2000-2006 (Bùi Trinh, 2013). Lao động hay vốn vật chất không phải là những nguồn lực vô hạn cho tăng trưởng. Lực lượng lao động của Việt Nam vẫn gia tăng nhưng tỷ trọng lao động trẻ ngày cảng giảm do dân số đang già hóa. Sự phụ thuộc của tăng trưởng vào vốn (Hình 10), được hỗ trợ bởi sự mở rộng tín dụng liên tục trong nhiều năm đã dẫn tới hệ quả là tăng trưởng thiếu bền vững, đi kèm những bất ổn kinh tế vĩ mô.

\section{Hình 6: Gross fixed capital formation (\%GDP)}

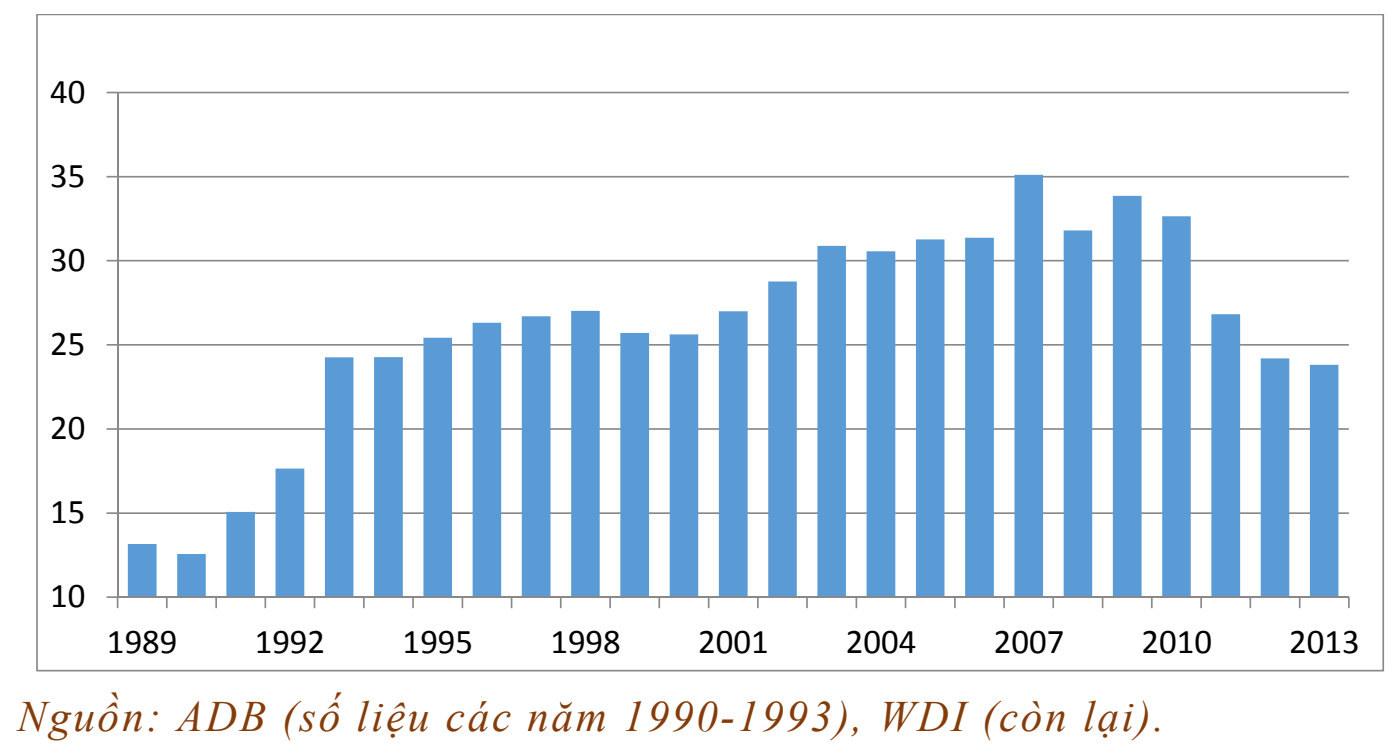


Sau nhiều năm tín dụng liên tục được mở rộng, lạm phát cao xảy ra như một hệ quả tất yếu.Tín dụng tăng trưởng ở mức cao từ năm 2000 liên tục cho tới năm 2010 với tốc độ tăng bình quân 32\%/năm, đạt đỉnh năm 2007 ở mức xấp xỉ 54\%. Khi nguồn cung tiền tệ có tốc độ tăng trưởng lớn hơn tốc độ tăng trưởng GDP, trong trường hợp Việt Nam là lớn hơn rất nhiều, tất yếu dẫn tới lạm phát cao. Thực tế, đây là điều đã xảy ra ở Việt Nam từ sau năm 2008.Việt Nam có kim ngạch xuất khẩu tính trên GDP khá lớn, nhưng phần lớn hàng xuất khẩu có nguồn gốc từ nhập khẩu, nên lạm phát cao những 2008-2011 cũng chịu tác động của giá cả tăng cao trên thị trường quốc tế. Vì vậy, nền kinh tế rất dễ bị tổn thương trước những biến động bên ngoài.

Tương quan nghịch biến giữa tăng trưởng và lạm phát cho thấy một bức tranh khác: không nhất thiết phải đánh đổi tăng trưởng với lạm phát (Hình 7). Thực trạng này phần nào lý giải vì sao tăng trưởng của Việt Nam suy giảm cả những năm sau khủng hoàng tài chính toàn cầu và chỉ bắt đầu phục hồi từ năm 2013, khi chính phủ đặt trọng tâm vào kiềm chế lạm phát thay vì tăng trưởng bằng mọi giá như giai đoạn trước.Đầu tư kém hiệu quả, đặc biệt là đầu tư công, là một nhân tố khác gây ra sự thiếu ổn định kinh tế vĩ mô và chất lượng tăng trưởng thấp. Hệ số ICOR của khu vực kinh tế nhà nước trong giai đoạn 2006-2010 đã tăng lên 9,7 từ mức 6,9 của giai đoạn 2000-2005. Đầu tư công lớn, nhưng kém hiệu quả, trong khi khả năng cung ứng nội tại của nền kinh tế yếu kém làm giá cả hàng hóa tăng.Lượng đầu tư cao đồng nghĩa với việc phải chi phí nhiều nguồn lực để tạo ra thêm một sản phẩm đầu ra.Điều này tạo ra lạm phát chi phí đẩy.

\section{Hình 7: Tăng trưởng GDP và Lạm phát (1989-2014)}

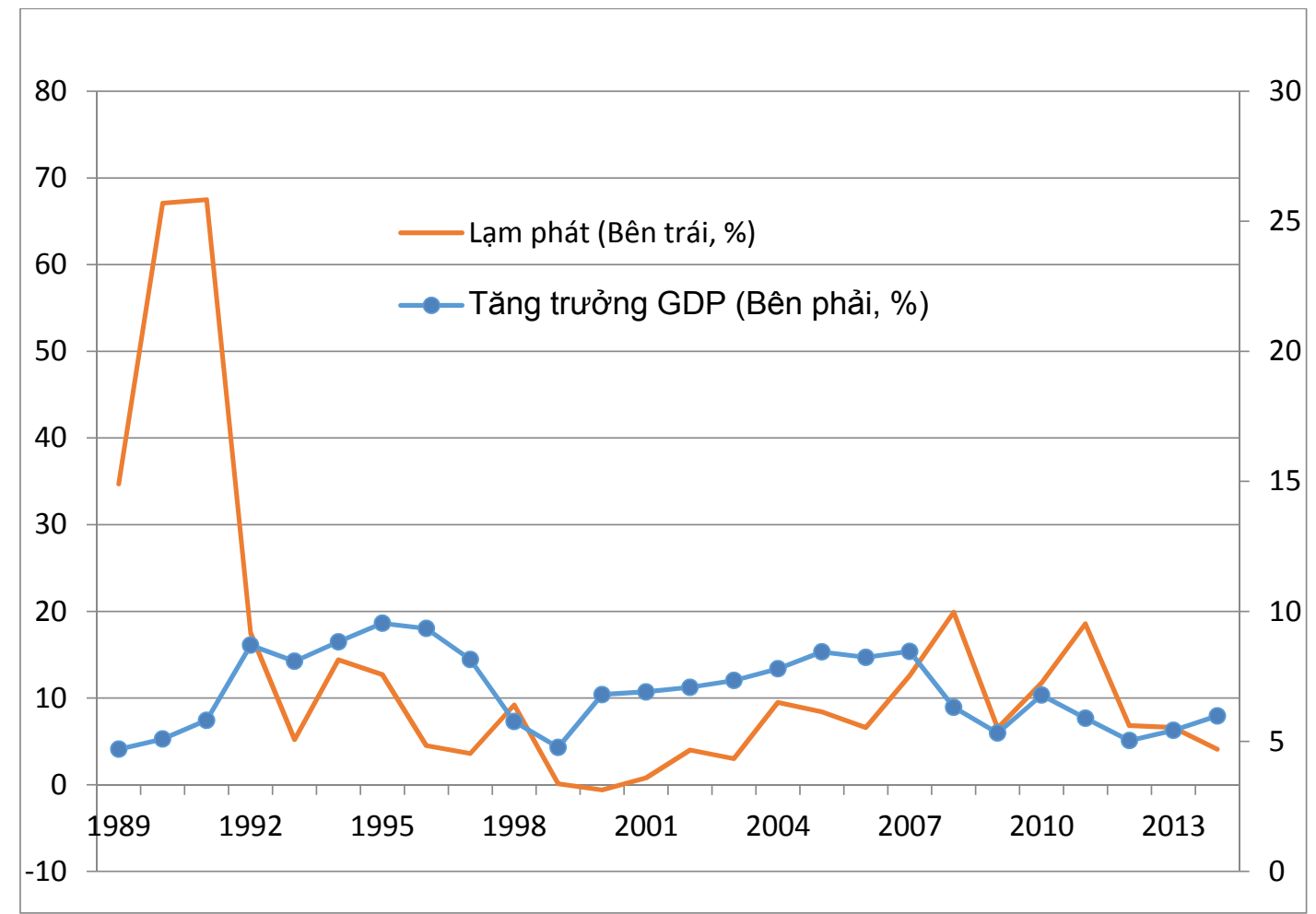

Nguồn: Xủ lý tù dũ liệu Niêm giám Thống kê-TCTK 
Nên lưu ý rằng trong giai đoạn 1991-1996, tổng đầu tư/GDP của Việt Nam bình quân chỉ là $23 \%$, ICOR chung chỉ khoảng 2,7 , nghĩa là hiệu quả đầu tư rất cao (Mekong Economics, 2013). Nhưng giai đoạn sau đó, dưới tác động mạnh của hai đợt kích cầu kiểu ưu đãi - xin cho và cách phản ứng hành chính trước các cú sốc mạnh từ bên ngoài, những thành tích này đã không còn duy trì được.Hiệu quả và chất lượng tăng trưởng - phát triển sụt giảm mạnh, có nguyên nhân từ việc nền kinh tếkhông tiếp tục duy trì được đà cải cách thị trường như giai đoạn trước.

Xu hướng tăng lên nhanh của ICORlà từ sau năm 1996, và chủ yếu là từ khu vực kinh tế nhà nước.Dù từ sau năm 2010,ICOR của khu vực này có cải thiện, song vẫn cao hơn giai đoạn 2000-2005, và cao nhiểu so với khu vực tư nhân và khu vực FDI (Hình 8).Vì vậy, cho dù kinh tế nhà nước chiếm tỷ trọng lớn nhất trong tổng đầu tư toàn xã hội tính đến hết 2013 (Bảng 2), thì tăng trưởng cũng như tạo việc làm lại chủ yếu lại đến từ khu vực tư nhân (Hình 5). Tỷ trọng đầu tư của khu vực nhà nước giảm đi không có nghĩa là khu vực này giảm đầu tư về con số tuyệt đối.Trên thực tế, nhiều nguồn lực tài chính của nền kinh tế vẫn đang được phân bổ không “đúng người, đúng chỗ và đúng lúc", do vậy, vẫn bị sử dụng một cách lãng phí hàng năm.

\section{Hình 8: Hệ số ICOR theo các khu vụ̣c kinh tế (1996-2011)}

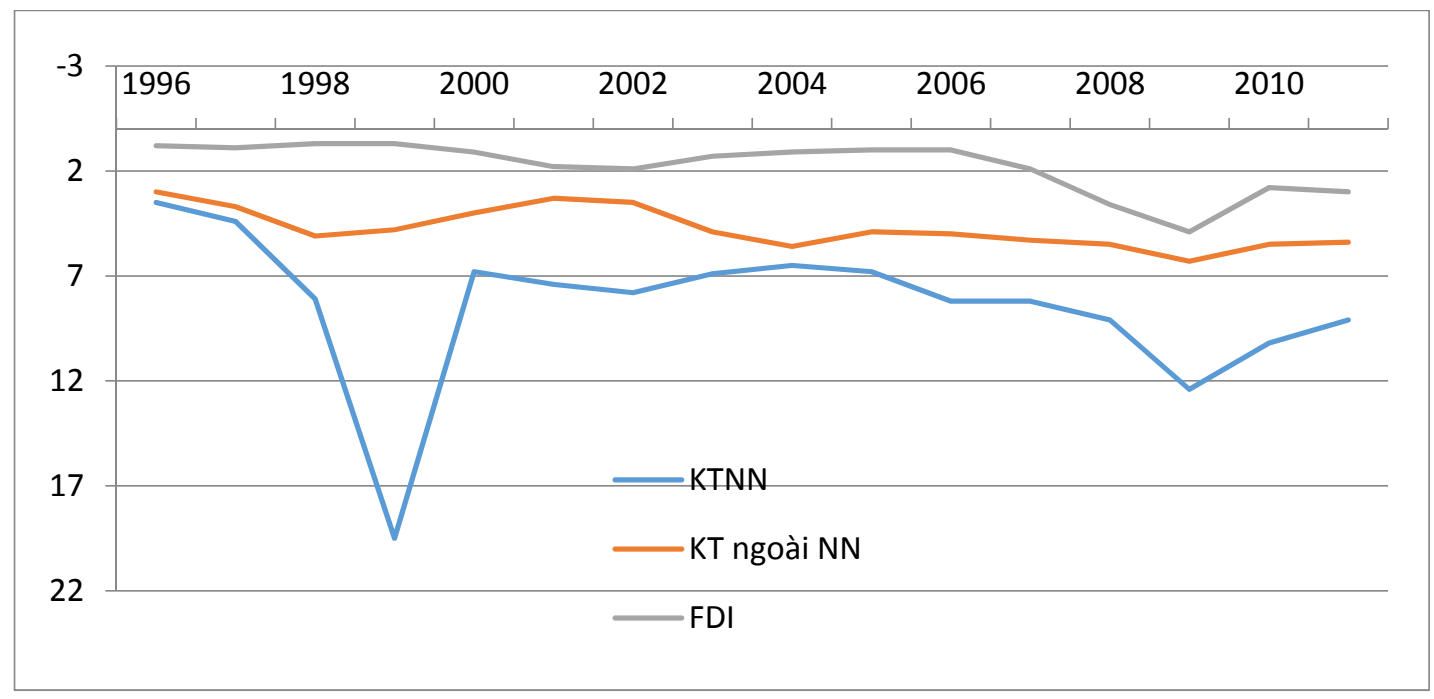

Nguồn: Niên giám Thống kê - TCTK.

Kết hợp những dữ liệu về đầu tư, trong cơ cấu GDP và cơ cấu lao động, dễ dàng chỉ ra sự méo mó trên thị trường đang diễn ra hiện nay trong nền kinh tế là do khu vực DNNN. Hiệu quả đầu tư thấp, trong khi Việt Nam vẫn có mức tăng trưởng ở mức khá so với nhiều nước đang phát triển khác. Vì thế, thiếu vốn đầu tư không phải là một ràng buộc cứng để đạt được tăng trưởng kinh tế cao, mà là hiệu quả sử dụng vốn. Điều này được phản ánh rõ khi so sánh Việt Nam với một số quốc gia như chỉ ra trong Bảng 6 .

Sự hạn chế về năng lực quản lý của nhà nước, hiệu quả đầu tư của khu vực DNNN, tình trạng tham nhũng, là những nguyên nhân giải thích tại sao ICOR ở Việt Nam tăng 
cao trong nhiều năm vừa qua. Nếu như đồng vốn được sử dụng nhiều hơn vào việc cải thiện trình độ công nghệ và cải tiến quy trình, hay cho đầu tư nghiên cứu triển khai, thì tăng trưởng TFP chắc hẳn phải cao hơn mức hiện tại, hệ số ICOR sẽ giảm, và nền kinh tế đạt được tốc độ tăng trưởng cao hơn.

Là một quốc gia đang phát triển, nhu cầu vốn đầu tư lớn là tất yếu.Nhưng ngay cả khi có lượng vôn lớn mà sử dụng không hiệu quả thì có thể dẫn tới kết quả không mong đợi. Xu thế gia tăng tỷ trọng đầu tư trong GDP nhiều năm qua ở Việt Nam phản ánh lựa chọn tăng trưởng dựa vào đầu tư trong nhiều năm sau Đổi mới.Xu hướng nàychỉ được đảo ngược từsau năm 2010.

Tỷ trọng đầu tư trong cơ cấu GDP và ICOR giảm xuống là một tín hiệu tốt nếu xu hướng này là kết quả từ những thay đổi về cấu trúc. Tuy nhiên, khi khu vực nhà nước vẫn chiếm tỷ trọng đầu tư lớn nhất, không gian tài khóa bị thu hẹp gây ra bởi ngân sáchthâm hụt nhiều năm ở mức cao liên tục và nợ công đang tiến sát ngưỡng an toàn giải thích cho xu hướng giảm tỷ trọng đầu tư trong GDP.

\section{Bảng 3: Tăng trưởng, đầu tư và hiệu quả đầu tư một số nước}

\begin{tabular}{|c|c|c|c|}
\hline Quốc gia & Giai đoạn & Tăng trưởng (\%) & ICOR \\
\hline Việt Nam & $1997-2007$ & 7.2 & 5.1 \\
\hline Hàn Quốc & $1969-1988$ & 8.4 & 2.8 \\
\hline Malaysia & $1977-1996$ & 7.4 & 4.9 \\
\hline Thái Lan & $1976-1995$ & 8.1 & 3.6 \\
\hline Đài Loan & $1963-1982$ & 9.8 & 2.9 \\
\hline Indonesia & $1977-1996$ & 7.2 & 2.8 \\
\hline
\end{tabular}

Nguồn: Nguyễn Xuân Thành and David Dapice (2009)

Tăng trưởng không chỉ dựa vào đầu tư nội địa mà còn dựa vào FDI. Nhung tăng trưởng dụa vào vốn FDI về dài hạn là không bền vũng (World Bank, 2012; Ohno, 2010). Khu vực FDI ở Việt Nam chiếm khoảng $25 \%$ tổng vốn đầu tư toàn xã hội, tạo ra khoảng $70 \%$ GTSX công nghiệp, nhưng chỉ tạo ra lượng việc làm tương đối nhỏ, chưa đến 5\% (khoảng 1,78 triệu - Báo cáo Điều tra lao động việc làm 2013, TCTK). Số lượng các sản phẩm chủ lực tăng lên hàng năm, nhưng chỉ tập trung vào một số mặt hàng truyền thống, có trình độ công nghệ thấp và không mang lại giá trị tăng cao, như dệt may, thủy sản, da - giày, còn các sản phẩm công nghệ như điện thoại, máy tính, thiết bị điện tử chủ yếu là nhờ khu vực FDI.

Cơ cấu công nghệ của sản phẩm xuất khẩu cả nước cho thấy vì sao có ý kiến cho rằng Việt Nam là điểm đến của công nghệ trung bình và lạc hậu (Bảng 4). Vì thế, FDI thể không tạo ra lan tỏa công nghệ sang khu vực nội địa thấp, cũng không thúc đẩy quá trình nâng cao kỹ năng người lao động, gián tiếp ảnh hưởng tới tăng trưởng năng suất lao động cũng như năng suất tổng nhân tố.Dữ liệu Bảng 5 cho thấy, Việt Nam xếp hạng rất thấp trong khu vực về trình độ công nghệ của sản phẩm tinh chế trong cơ cấu sản phẩmxuât 
khẩu, và việc cải thiện là rất hạn chế. Điều ghi nhận được ở đây chính là tỷ lệ sản phẩm thâm dụng tài nguyên giữ ở mức thấp hơn nhiều so với của Singapore, Thái Lan hay Indonesia.Vì vậy, nhìn ở góc độ công nghệ của sản phẩm xuất khẩu, chưa hẳn đúng khi nói Việt Nam đã tận dụng tốt cơ hội của mở cửa và hội nhập.Thay vào đó, các nhà đầu tư nước ngoài đã biến lợi thế lao động rẻ ở Việt Nam thành lợi thế của họ để chuyển vào những công nghệ lạc hậu.

\section{Bảng 4: Trình độ công nghệ của sản phẩm tinh chế (manufactured goods)xuất khẩu} của Việt Nam và một số nước (2000 và 2009)

\begin{tabular}{|c|c|c|c|c|c|c|c|c|}
\hline & \multicolumn{4}{|c|}{2000} & \multicolumn{4}{|c|}{2009} \\
\hline Công nghệ & Cao & $\begin{array}{l}\text { Trung } \\
\text { bình }\end{array}$ & Thấp & $\begin{array}{l}\text { Thâm } \\
\text { dụng tài } \\
\text { nguyên }\end{array}$ & $\mathrm{Cao}$ & $\begin{array}{l}\text { Trung } \\
\text { bình }\end{array}$ & Thấp & $\begin{array}{l}\text { Thâm } \\
\text { dụng tài } \\
\text { nguyên }\end{array}$ \\
\hline Việt Nam & $11 \%$ & $10 \%$ & $65 \%$ & $14 \%$ & $12 \%$ & $13 \%$ & $62 \%$ & $12 \%$ \\
\hline Trung Quốc & $21 \%$ & $24 \%$ & $45 \%$ & $9 \%$ & $32 \%$ & $28 \%$ & $32 \%$ & $8 \%$ \\
\hline Cambodia & $0 \%$ & $1 \%$ & $93 \%$ & $6 \%$ & $0 \%$ & $3 \%$ & $96 \%$ & $1 \%$ \\
\hline Indonesia & $15 \%$ & $20 \%$ & $32 \%$ & $34 \%$ & $7 \%$ & $24 \%$ & $23 \%$ & $47 \%$ \\
\hline Ấn Độ & $5 \%$ & $13 \%$ & $47 \%$ & $34 \%$ & $10 \%$ & $19 \%$ & $31 \%$ & $40 \%$ \\
\hline Hàn Quốc & $35 \%$ & $35 \%$ & $18 \%$ & $12 \%$ & $30 \%$ & $46 \%$ & $11 \%$ & $13 \%$ \\
\hline Malaysia & $55 \%$ & $21 \%$ & $10 \%$ & $14 \%$ & $43 \%$ & $22 \%$ & $13 \%$ & $23 \%$ \\
\hline Philippines & $69 \%$ & $12 \%$ & $12 \%$ & $7 \%$ & $62 \%$ & $18 \%$ & $8 \%$ & $13 \%$ \\
\hline Đài Loan & $43 \%$ & $28 \%$ & $24 \%$ & $4 \%$ & $38 \%$ & $32 \%$ & $18 \%$ & $11 \%$ \\
\hline Thái Lan & $32 \%$ & $27 \%$ & $22 \%$ & $19 \%$ & $24 \%$ & $36 \%$ & $17 \%$ & $24 \%$ \\
\hline Singapore & $59 \%$ & $21 \%$ & $7 \%$ & $13 \%$ & $45 \%$ & $22 \%$ & $7 \%$ & $26 \%$ \\
\hline
\end{tabular}

MPI and Unido (2011) và CIEM (2011).

Ghi chú: Số liệu của Singapore là của năm 2000 và năm 2008.

Ngoài ra, FDI thường tập trung vào các địa phương có môi trường kinh doanh thuận lợi, hạ tầng phát triển, nên sẽ làm gia tăng khoảng cách phát triển giữa các địa phương, sẽ tác động không nhỏ tới các quá trình hoạch định chính sách an sinh xã hội và hài hòa xã hội. Khu vực FDI, nhấtlà trong các khu công nghiệp, có đóng góp không nhỏ vào tình trạng ô nhiễm môi trường,khiến cho chi phí khắc phục môi trường trong tương lai có thể xóa đi những lợi ích trước mắt mà khu vực này mang lại. Trung Quốc ước tính mỗi năm cần $10 \%$ GDP để trả lại môi trường như nguyên trạng (Halldings, 2014).

b. Quá trình tái cầu trúc nền kinh tế đang diễn ra không như kỳ vọng, diễn ra rất chậm.

Quy mô kinh tế nhà nước không những không giảm mà lại còn tăng lên. Lao động làm việc trong khu vực nhà nước vào cuối năm 2013 là trên 5,33 triệu, tăng mạnh so với 
con số 4,794 triệu vào cuối năm 2009. Điều này giải thích tại sao chi thường xuyên trong cơ cấu chi NSNN có xu hướng ngày càng tăng lên, hiện đã đạt khoảng $70 \%$. Cổ phần hóa DNNN còn mang tính hình thức, cố giữ tỷ lệ vốn sở hữu nhà nước "áp đảo", lấy đó làm cơ sở chủ yếu "giữ định hướng XHCN", thực chất chưa làm thay đổi cấu trúc quản trị, do đó, không đạt được mục tiêu cải cách hướng tới tăng cường hiệu quả hoạt động kinh doanh của doanh nghiệp, cải thiện phần đóng góp ngân sách, thậm chí lại tạo cơ hội cho các nhóm lợi ích trục lợi. Đó là lý do giải thích tại sao hiệu quả đầu tư, chỉ sốICOR ít được cải thiện.

Tương tự là tái cơ cấu hệ thống các Tổ chức tín dụng (TCTD). Giải pháp xử lý nợ xấu hiện nay đang nhằm vào mục tiêu "dọn dẹp" sân bãi, tháo dỡ các rào cản tạm thời nhưng chưa đi vào xử lý thực chất và triệt để nợ xấu theo đúng nguyên tắc thị trường.Cấu trúc quản trị và tổ chức hoạt động của các tổ chức tín dụng chưa có nhiều thay đổi.

Tái cơ cấu đầu tư công dường như có tiến triển khi tỷ trọng đầu tư công/GDP có xu hướng giảm trong gần một thập niên qua.Nhưng như đã đề cập, điều này không có nghĩa là lượng vốn đầu tư của khu vực nhà nước suy giảm, mà là do đầu tư tư nhân và khu vực FDI đã mở rộng đáng kể cùng với đó là không gian tài khóa trong cân đôi NSNN đã thu hẹp.Tình trạng bội chi ngân sách ở mức cao (gần như thường xuyên duy trì ở mức $5 \%$ GDP), luôn song hành với gia tăng chi thường xuyên là một sự minh chứng rõ nhất cho những nỗ lực chưa thành công của sự nghiệp cải cách hành chính và cải cách khu vực công.Tình trạng vay nợ (qua phát hành trái phiếu) để đảo các khoản nợ cũ của Chính phủ có thể dẫn tới những hệ lụy khôn lường cho tăng trưởng dài hạn. Bởi việc này sẽ làm gia tăng các khoản nợ trong tương lai.

\section{c. Doanh nghiệp tư nhân nội địa phát triển không bền vững.}

Trong 3 năm gần đây, số lượng doanh nghiệp phá sản hoặc ngừng hoạt động tăng lên, năm 2010 là 47 nghìn, năm 2013 là 61 nghìn, nửa đầu năm 2014 là 34 nghìn (World Bank, 2014). Nguyên nhân ẩn phía sau những con số này một phần là do kinh tế trong và ngoài nước chưa phục hồi, nhưng phần lớn là do không tìm được thị trường và tiếp cận vốn vay, bên cạnh nguyên nhân do chi phí đầu vào tăng cao. Gần $95 \%$ doanh nghiệp Việt Nam là thuộc hệ "doanh nghiệp vừa và nhỏ"(VCCI, 2013) [thực chất là doanh nghiệp nhỏ và siêu nhỏ], và chỉ có khoảng $15 \%$ trong số này có thể tiếp cận tín dụng chính thức. SMEs có xu hướng tìm nguồn tín dụng phi chính thức hơn là từ ngân hàng do những ràng buộc về tài sản đảm bảo; bình quân mỗi SME ở Việt Nam thiếu 42,000 USD vốn tín dụng (Wignaraja and Jinjarak, 2014 - ADB working paper).

Ở khía cạnh khác, năng lực công nghệ của doanh nghiệp "nội" là hết sức lo ngại.Năm 2011, chỉ có $0,005 \%$ DN có sáng kiến khoa học (VCCI, 2013). Báo cáo năng lực cạnh tranh toàn cầu năm 2012 - 2013 của Diễn đàn kinh tế thế giới (WEF 2013) chỉ ra rằng, mức độ hấp thụ công nghệ của nước ta đứng vị trí rất thấp (98/133). Thêm nữa, quy mô doanh nghiệp có xu hướng nhỏ lại. Năm 2007, doanh nghiệp siêu nhỏ chiếm tỷ trọng 61,4\% thì đển năm 2012 đã tăng lên 66,8\% (VCCI, 2013). Một số doanh nghiệp lớn lên nhà nhờ vào quá trình đầu tư và đầu cơ tài sản thay vì phát triển sản xuất, rõ rệt nhất là trong ngành bất động sản. Việt Nam không có tỷ phú công nghiệp. Một số thương hiệu 
nội địa mạnh thậm chí đang mất vào tay nhà đầu tư nước ngoài, như Kinh Đô đã bán $80 \%$ cổ phần cho Mondelèz International.

\section{d. Năng suất lao động thấp và tăng trưởng năng suất lao động lại có xu hướng giảm.}

Đây là một thách thức nữa cho mục tiêu tăng trưởng dài hạn ở Việt Nam. Trong những năm 1990, tăng trưởng kinh tế cao đi kèm với tốc độ tăng trưởng năng suất lao động tăng nhanh (World Bank, 2013), nhưng giai đoạn về sau lại chứng kiến tăng trưởng năng suất lao động sụt giảmmạnh. Trong giai đoạn 2000-2006, năng suất lao động tăng bình quân gần $6 \% /$ năm, giảm xuống còn khoảng 3\%/năm trong giai đoạn 2007-2013 (CIEM, 2014). Trong đó, chuyển dịch cơ cấu kinh tế đóng góp $50 \%$, điều cho thấy sau hơn 2 thập niên đổi mới, nền kinh tế vẫn chưa tiệm cận tới điểm chuyển Lewis (Lewis's turning point), nghĩa là vẫn đang trong giai đoạn chuyển dịch từ khu vực nông nghiệp sang khu vực công nghiệp và dịch vụ, chứ chưa đạt được mức độ tích tụ công nghiệp đủ lớn.Việc chuyển sang một nền kinh tế công nghiệp và hiện đại như thể chưa bắt đầu. Mục tiêu đạt mức GDP bình quân đầu người 3.000USD vào 2020 (trong Chiến lược Phát triển Kinh tế - Xã hội giai đoạn 2011-2020) trở nên thiếu thực tế, bởi điều này tương ứng kể từ 2015 trở đi Việt Nam phải đạt được mức tăng trưởng thu nhập đầu người trên $10 \%$ mỗi năm.

Tăng trưởng năng suất lao động có quan hệ mật thiết với kỹ năng của người lao động. Các nhà tuyển dụng ở Việt Nam đang gặp nhiều khó khăn trong việc tìm kiếm lao động đủ kỹ năng làm việc mặc dù sẵn sàng trả lương cao hơn (World Bank, 2013). Hiện trạng này là rất nghịch lý khi đặt trong mối quan hệ với kết quả PISA của Việt Nam, nhưng nó chỉ rõ một thực tế là hệ thống giáo dục của Việt Nam mới chỉ làm tốt ở khâu phổ biến kiến thức hàn lâm, chứ chưa thực hiện việc biến những tri thức trường lớp thành những kỹ năng hành động.

\section{e. Bất bình đẳng gia tăng}

Mục tiêu tăng trưởng hài hòa cũng có những rủi ro. Bất bình đẳng gia tăng cho thấy cơ sở cho tăng trưởng bao trùm dài hạn còn nhiều thách thức. Khoảng cách thu nhập giữa nhóm giàu nhất và nhóm nghèo nhất trong hơn 2 thập kỷ qua vẫn trong xu hướng tăng lên, từ mức 6,5 lần năm 1994 lên 8,34 năm 2004 và tiếp tục tăng lên 9,35 năm 2012 (Kêt quả KSMS nhiều năm).

Vẫn có khoảng $70 \%$ dân số Việt Nam sống ở nông thôn và có sinh kế chủ yếu từ sản xuất nông nghiệp, có thu nhập thấp và đang ngày càng bị tụt lại khi so sánh với thu nhập của dân cưđô thị. Tình trạng bất bình đẳng có chiều hướng gia tăng có thể dẫn tới những vấn đề lớn cho chính phủ trong công tác an sinh xã hội. Hơn nữa, đối tượng chịu ảnh hưởng của bất bình đẳng chiếm tỷ trọng lớn là trẻ em, nhất là ở vùng khó khăn, dân tộc thiểu số. Thiếu có điều kiện phát triển vốn con người có thể khiến Việt Nam gặp rủi ro thiếu nguồnnhân lực trình độ cao ở thế hệ tiếp theo cho phát triển kinh tế. Bất bình đẳng là một trong những nhân tố quyết định khả năng một nước đang phát triển thoát khỏi bẫy thu nhập trung bình (Ohno, 2010). 


\section{3. Định vị kinh tế Việt Nam}

\section{a. Kinh tế Việt Nam đứng ở đâu trong không gian khu vực và thế giới?}

Có thể định vị nền kinh tế Việt Nam trên hai phương diện có liên hệ chặt chẽ với nhau. Nhóm thứ nhất là dựa vào mức sống hay mức thịnh vượng của quốc gia, bao gồm cả tiêu chí về năng suất lao động và so sánh với các nước trên thế giới. Nhóm thứ hai dựa vào các chỉ số kinh tế - xã hội và thứ hạng của Việt Nam.

Cho dù vẫn còn nhiều thách thức trong phát triển kinh tế - xã hội, những thành tựu Việt Nam đạt được trong những năm qua xét trên nhiều phương diện thực sự là những thay đổi sâu sắc so với 3 thập niên trước.Việt Nam đã từng được ví như một con rồng tiếp theo của châu Á. Những thành tích kiểu như "đứng ở tốp đầu" trong các bảng xếp hạng toàn cầu- vị trí thứ 2 trong xuất khẩu cà phê, thứ 3 xuất khẩu lúa gạo, hay thứ 4 về xuất khẩu thủy hải sản (Fao, 2012), hay cả những thành tích dễ dàng kiểu "tăng trưởng quý sau cao hơn quý trước"hoặc"tăng trưởng tín dụng hàng năm đạt hoặc vượt kế hoạch đề ra từ đầu năm"dễgây ra tâm lý thỏa mãn và "say sưa vì thắng lợi".

Tuy nhiên, tất cả những điều này sẽ trở nên ít ý nghĩa khi định vị Việt Nam trong không gian kinh tế toàn cầu.

Một thực tế là tăng trưởng năng suất lao động ở Việt Nam đã sụt giảm trong giai đoạn mấy năm vừa qua. Đang dấy lên quan ngại rằng nó sẽ kéo tăng trưởng kinh tế cả nước đi xuống và Việt Nam có thể đã rơi vào bẫy thu nhập trung bình. Tuy nhiên, vấn đề vị thế kinh tế của Việt Nam không đơn thuần nằm ở xu thế của tăng trưởng năng suất lao động hay tăng trưởng GDP, mà tronggiai đoạn này, quan trọng hơn, do đó, đúng hơn là nằm ở điểm xuất phát thấp của Việt Nam hơn so với các quốc gia đi trước.

Bảng 5: Tăng trưởng năng suất lao động một số quốc gia (1990-2012)

\begin{tabular}{|l|r|r|r|r|}
\hline \multicolumn{1}{|c|}{ Giai đoạn } & \multicolumn{1}{c|}{$\mathbf{1 9 9 0 - 1 9 9 5}$} & \multicolumn{1}{c|}{$\mathbf{1 9 9 5 - 2 0 0 0}$} & \multicolumn{1}{c|}{$\mathbf{2 0 0 0 - 2 0 0 5}$} & \multicolumn{1}{c|}{$\mathbf{2 0 0 5}-\mathbf{2 0 1 2}$} \\
\hline Trung Quốc & 10.6 & 7.1 & 8.6 & 9.5 \\
\hline Ấn Độ & 2.6 & 3.4 & 2.6 & 6.9 \\
\hline Việt Nam & $\mathbf{5 . 4}$ & $\mathbf{5 . 3}$ & $\mathbf{5 . 5}$ & $\mathbf{3 . 6}$ \\
\hline Indonesia & 5.7 & -1.5 & 3.7 & 3.4 \\
\hline Hàn Quốc & 5 & 4.2 & 2.9 & 2.4 \\
\hline Thailand & 8.2 & 0.4 & 2.9 & 2.2 \\
\hline Phillipines & -0.1 & 2.9 & 1.1 & 3 \\
\hline Malaysia & 6.6 & 0.9 & 3 & 1.4 \\
\hline Singapore & 4.1 & 3.7 & 3.1 & 0.4 \\
\hline Asean 6 & 5.4 & 0 & 2.9 & 2.7 \\
\hline
\end{tabular}

Nguồn: APO Productivity Database 2014

Chỉ tiêu thường được sử dụng khi so sánh ở cấp độ quốc tế là GDP/đầu người (giá cố định hoặc giá $\mathrm{PPP}$ ).Hãy tạm chưa tính tới chỉ tiêu này, mà hãy xem xét hai chỉ tiêu khác là GDP/công nhân, và GDP/nhân công nông nghiệp. Ở chỉ tiêu đầu tiên, dù là lấy năm 1970, 1980 hay 2000 làm năm cơ sở để so sánh, thì xuất phát điểm của Việt Nam đều thấp hơn phần lớn các quốc gia khác (Bảng 6). Điều đáng bàn ở đây là khoảng cách 
tuyệt đối về năng suất lao động của công nhân Việt Nam và các nước đang tăng nhanh. Vì thế, cho dù năng suất lao động ở Việt Nam dù có cao hơn những nước thuộc nhóm thu nhập cao thì khoảng cách thực tế về mức độ thịnh vượng quốc gia vẫn ngày một lớn hơn.

Bảng 6: GDP/nhân công ở một số nền kinh tế (1970-2012)

\begin{tabular}{|l|r|r|r|r|r|r|}
\hline Quốc gia & $\mathbf{1 9 7 0}$ & $\mathbf{1 9 8 0}$ & $\mathbf{1 9 9 0}$ & $\mathbf{2 0 0 0}$ & $\mathbf{2 0 1 0}$ & $\mathbf{2 0 1 2}$ \\
\hline Singapore & 30,6 & 43,2 & 64,5 & 95,3 & 113,7 & 114,4 \\
\hline Nhật Bản & 26,3 & 37,6 & 53,9 & 60,3 & 66,2 & 66,9 \\
\hline Hàn Quốc & 8,3 & 13,4 & 25,2 & 40,0 & 53,8 & 54,8 \\
\hline Malaysia & 12,4 & 19,0 & 25,0 & 36,4 & 45,0 & 46,6 \\
\hline Thailand & 5,1 & 7,1 & 11,1 & 16,9 & 21,8 & 22,9 \\
\hline Indonesia & 5,1 & 8,1 & 10,6 & 13,1 & 18,1 & 20,0 \\
\hline Trung Quốc & 1,0 & 1,5 & 2,3 & 5,6 & 14,5 & 16,9 \\
\hline Philippines & 9,1 & 10,7 & 9,8 & 11,3 & 13,7 & 14,7 \\
\hline Ân Độ & 3,5 & 3,9 & 4,8 & 6,4 & 11,1 & 11,9 \\
\hline Viet Nam & $\mathbf{2 , 3}$ & $\mathbf{2 , 4}$ & $\mathbf{2 , 7}$ & $\mathbf{4 , 7}$ & $\mathbf{7 , 4}$ & $\mathbf{7 , 9}$ \\
\hline
\end{tabular}

Đơn vị: 1.000 USD theo giá PPP năm 2011.

Nguồn:APO Productivity Database 2014.

Sản xuất nông nghiệp vốn từ lâu được coi là một thế mạnh của Việt Nam.Thực tế, lĩnh vực nông nghiệp vẫn đang là nguồn sinh kế chính của phần lớn dân cư trong nước. Do vậy, bức tranh so sánh quốc tế của Việt Nam dễ trở nên "thiếu sáng" ở tiêu chí năng suất lao động. Việc chỉ nhìn vào vị trí của Việt Nam trong bảng xếp hạng các quốc gia xuất khẩu gạo, cà phê, dệt may, thủy hải sản dễ khiến bất cứ ai cũng phải trầm trồ về vị thế của Việt Nam. Tuy nhiên, dữ liệu WDI cho biết, vào năm 1990, bình quân một công nhân trong ngành nông nghiệp tạo ra giá trị gia tăng tương đương 266 USD (theo giá cố định năm 2005), đến năm 2000 tăng lên 355 USD và lên 476 USD vào năm 2013. Về mặt tuyệt đối, năng suất lao động nông nghiệp đã tăng lên đều đặn trong hơn 20 năm qua. Nhưng việc so sánh tỷ lệ giữa giá trị gia tăng nông nghiệp/nhân công Việt Nam với một quốc gia và nhóm quốc gia khác lại cho thấy nền nông nghiệp Việt Nam đang ngày càng tụt hậu. Năng suất lao động nông nghiệp của Việt Nam chỉ tương đương $1 \%$ của Singapore, bằng 1-4\% của Nhật Bản, Hàn Quốc hay các nước $\mathrm{OECD}$; bằng khoảng $1 / 2$ của các nước thu nhập trung bình thấp (Bảng 7).

Đầu những năm 1990, năng suất lao động nông nghiệp Việt Nam tương đương $80 \%$ so với Trung Quốc, nhưng tỷ lệ này giảm bình quân mỗi năm 1 điểm phần trăm trong 3 thập niên qua. Xu hướng tương tự khi so sánh với các nước đang phát triển thuộc Đông Á và Thái Bình Dương. Khoảng cách chỉ có chút cải thiện so với Ấn Độ.

Viêc so sánh đơn giản 2 chỉ tiêu về năng suất lao động nói chung và riêng trong ngành nông nghiệp như trên cho thấy thực chất rất khiêm tốn của những thành tựu Việt Nam đạt được. Các so sánh tiếp sau đây sẽ củng cố những căn cứ chứng tỏ Việt Nam đang tụt lại xa trên đường đua với đích đến là trở thành một quốc gia giàu mạnh.

\section{Bảng 7: Tỷ lệ giá trị gia tăng/công nhân trong ngành nông nghiệpcủa Việt Nam so với một số nước}




\begin{tabular}{|l|c|c|c|c|c|c|c|c|}
\hline Năm & $\mathbf{1 9 9 0}$ & $\mathbf{1 9 9 3}$ & $\mathbf{1 9 9 6}$ & $\mathbf{2 0 0 0}$ & $\mathbf{2 0 0 4}$ & $\mathbf{2 0 0 7}$ & $\mathbf{2 0 1 0}$ & $\mathbf{2 0 1 3}$ \\
\hline Japan & $2 \%$ & $2 \%$ & $2 \%$ & $1 \%$ & $1 \%$ & $1 \%$ & $1 \%$ & - \\
\hline Singapore & $1 \%$ & $1 \%$ & $1 \%$ & $1 \%$ & $1 \%$ & $1 \%$ & $1 \%$ & $1 \%$ \\
\hline Korea, Rep. & $4 \%$ & $4 \%$ & $4 \%$ & $3 \%$ & $3 \%$ & $2 \%$ & $2 \%$ & $2 \%$ \\
\hline OECD members & $3 \%$ & $3 \%$ & $3 \%$ & $3 \%$ & $3 \%$ & $3 \%$ & $3 \%$ & $3 \%$ \\
\hline Malaysia & $6 \%$ & $6 \%$ & $6 \%$ & $6 \%$ & $6 \%$ & $6 \%$ & $5 \%$ & $5 \%$ \\
\hline Thailand & $41 \%$ & $43 \%$ & $41 \%$ & $44 \%$ & $43 \%$ & $43 \%$ & $43 \%$ & $41 \%$ \\
\hline Indonesia & $43 \%$ & $44 \%$ & $46 \%$ & $53 \%$ & $52 \%$ & $52 \%$ & $49 \%$ & $47 \%$ \\
\hline Lower middle income & $47 \%$ & $47 \%$ & $46 \%$ & $52 \%$ & $52 \%$ & $51 \%$ & $50 \%$ & $51 \%$ \\
\hline $\begin{array}{l}\text { East Asia \& Pacific (chín } \\
\text { tính nước đang phát triển) }\end{array}$ & $70 \%$ & $70 \%$ & $67 \%$ & $71 \%$ & $69 \%$ & $65 \%$ & $61 \%$ & $58 \%$ \\
\hline India & $58 \%$ & $60 \%$ & $59 \%$ & $67 \%$ & $71 \%$ & $69 \%$ & $69 \%$ & $68 \%$ \\
\hline China & $83 \%$ & $80 \%$ & $76 \%$ & $79 \%$ & $76 \%$ & $71 \%$ & $66 \%$ & $61 \%$ \\
\hline
\end{tabular}

Đo’n vị: \% (theo giá cố định 2005);

Nguồn: Tính toán tù dĩ liệu World Development Indicator

Nếu coi quy mô GDP là biểu hiện của sức mạnh kinh tế tổng hợp của quốc gia và lấy Trung Quốc làm cơ sở tham chiếu, Hình 13cho thấy sức mạnh kinh tế của Việt Nam ngày càng nhỏso với "gã khổng lồ" phía Bắc.Tại thời điểm khởi động đổi mới, quy mô GDP của Việt Nam (tính theo giá cố định năm 2005) tương đương với 4,1\% con số của Trung Quốc, tức 1/25. Nhưng tỷ lệ này không ngừng giảm xuống, đến 2013 chỉ còn 1,9\%. Sẽ là không khách quan nếu nhìn vào quy mô GDP Việt Nam và Trung Quốc để nhận định kinh tế Việt Nam đang tụt lại, bởi Trung Quốc đã trải qua một thời kỳ tăng trưởng cao "cá biệt" trong lịch sử kinh tế thế giới, và quy mô dân số của Trung Quốc gấp 15 lần Việt Nam. GDP/đầu người giá cố định hoặc tính theo PPP sẽ phản ánh đúng hơn mức độ thịnh vượng của quốc gia. Tuy nhiên, với cách tiếp cận tương tự, câu chuyện về vị thế của Việt Nam vẫn không mấy thay đổi. Tỷ lệ của cả hai tiêu chí tính trên bình quân đầu người vừa đề cập của Việt Nam so với Trung Quốc đều đang giảm xuống, trong đó độ dốc của đường tính theo giá PPP lớn hơn thể hiện mức độ thịnh vượng tương đối của người Việt Nam đang nhanh chóng giảm đi so với người Trung Quốc.

Vậy, đến 2035, tức sau 2 thập niên kể từ bây giờ và 50năm sau Đổi mới, Việt nam sẽ nằm ở đâu trên bản đồ kinh tế thế giới?Một so sánh khác trong Hình $14^{4}$ sẽ gợi ý thêm câu trả lời. Lấy dữ liệu GDP theo PPP năm 2005 trong cơ sở dữ liệu Penn World Table $8.0^{5}$ và lấy năm cơ sở là điểm bắt đầu mà các quốc gia có mức GDP/đầu người tương đối đồng đều nhau (dựa trên dữ liệu sẵn có), và giả định một kịch bản lạc quan nhất trong giai

${ }^{4}$ Ghi chú: Đơn vị: GDP giá hiện hành PPP 2005 (USD) - tính theo chi tiêu. Năm ghi trong ngoặc là năm co sở.

${ }^{5}$ Co' sở dũ liệu Penn World Table 8.0 hiện mói cập nhật tới dũ liệu tài khoản quốc gia đến 2011 
đoạn 2015-2015 Việt Nam sẽ tăng trưởng GDP/đầu người với mức 6\% trong 2015-2020 (tương đương với mức bình quân giai đoạn 2000-2011) và sau đó đạt bình quân $8 \%$ cho thời gian còn lại. Kết quả chỉ ra rằng, đến 2035 , mức độ thịnh vượng trung bình của người Việt Nam vẫn còn thua xa Đài Loan, Hàn Quốc, chỉ bằng gần một nửa của Nhật Bản và $1 / 3$ so với Singapore vào thời điểm 2011. Coi những giả định về tăng trưởng GDP/đầu người như trên là hợp lý, tính từ 2015,Việt Nam phải mất lần lượt 10,12 và 17 năm nữa để vượt qua mức Trung Quốc, Thái Lan và Malaysia đã đạt được ở năm 2011. Nói cách khác, sau 30 năm đổi mới, dù nhìn ở khía cạnh nào thì Việt Nam vẫn đang cách rất xa so với các nước đi trước.Nếu trong 2 thập kỷ tới, Việt Namkhông có những yếu tố đột phá vượt trội thì cục diện này sẽchẳng có gì thay đổi.

\section{Hình 9: Tỷ lệ GDP và GDP/đầu người Việt Nam so với Trung Quốc}

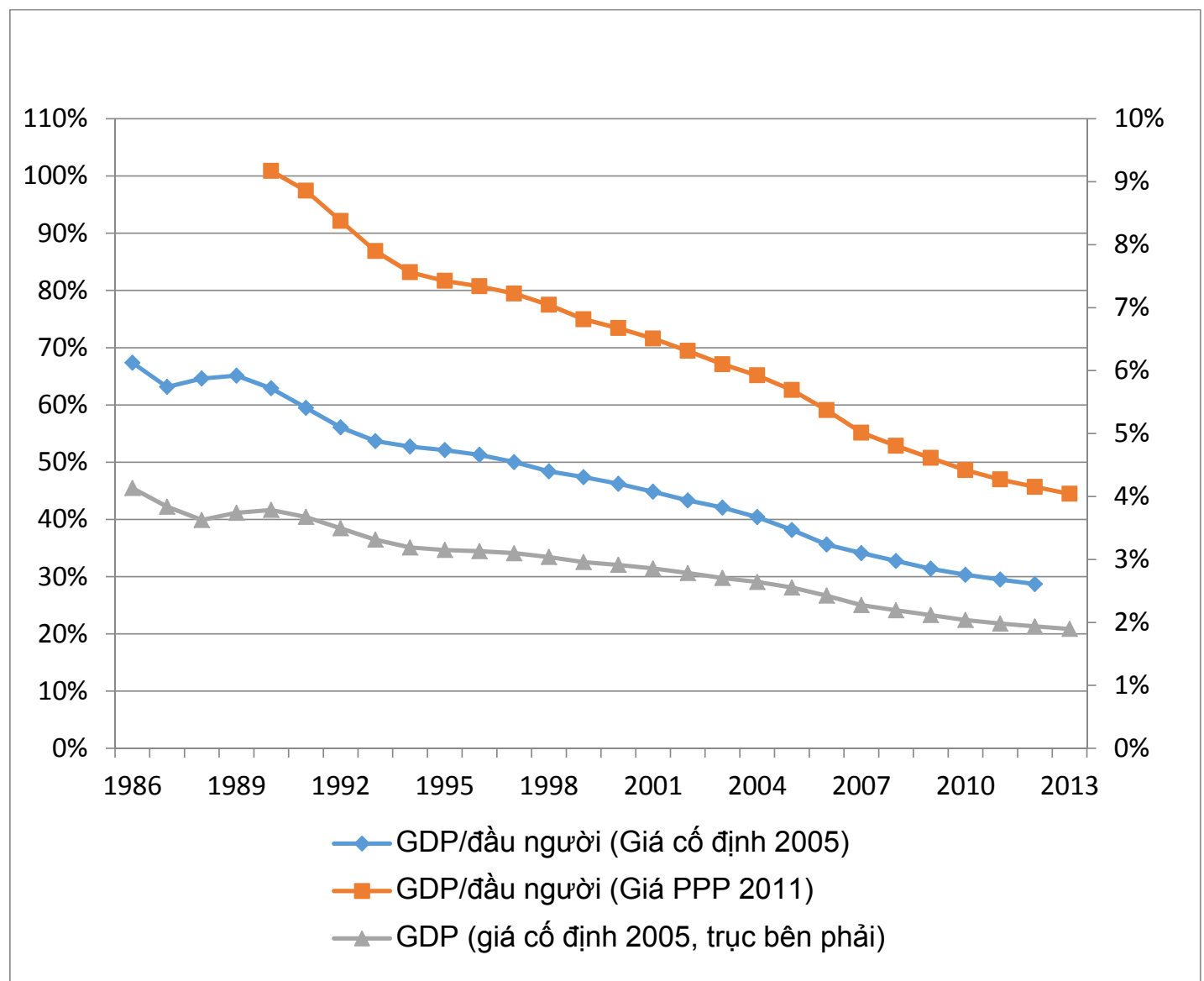

Nguồn: World Development Indicator

Không xét tới yếu tố vị trí địa lý, đưa Singapore vào nhóm quốc gia Đông Á và Trung Quốc vào nhóm các quốc gia Đông Nam Á, có thể thấy một xu thế phân biệt rõ rệt giữa hai nhóm này. Nhóm nước Đông Á đã có một giai đoạn tăng trưởng cao và vượt lên hẳn, trong khi nhóm nước Đông Nam Á sau nhiều hàng chục năm tiến hành cải cách kinh tế vẫn chưa thể bứt lên và gia nhập thế giới phát triển.

\section{Hình 10: So sánh mức độ thịnh vượng về dài hạn giữa các nước}




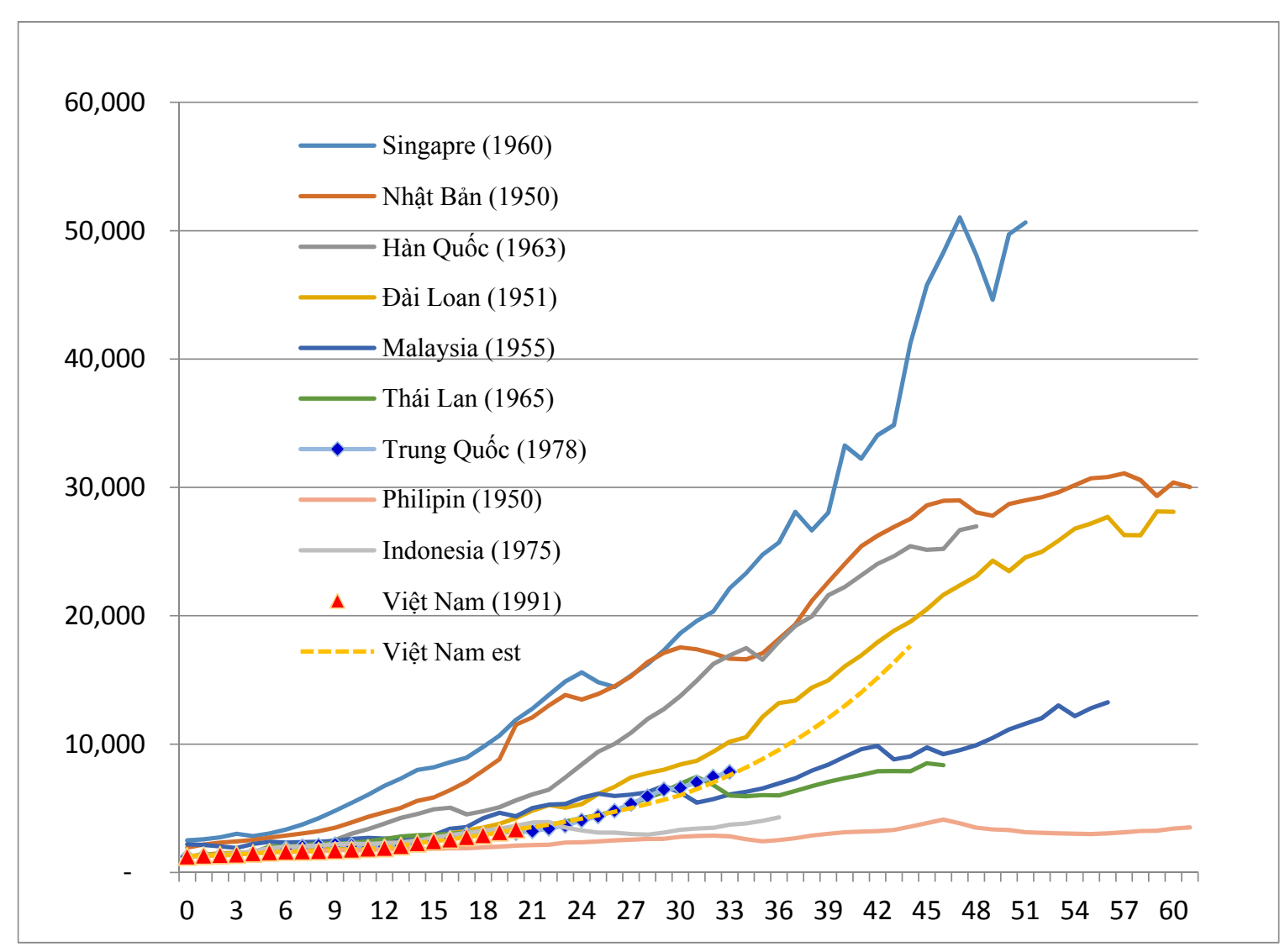

Nguồn: Penn World Table 8.0

Việt Nam tiến hành cải cách kinh tế chậm hơn khá lâu so với hầu hết các nước, nghĩa có lợi thế đi sau tuyệt đối.Nhưngdường như Việt Nam đã và đang cho thấy mình thuộc nhóm Đông Nam Á, và rất có thể đang lặp lại mô hình của những nước này.Philippines, Indonesia hay Thái Lan, hay ngay cả Trung Quốc dù đạt mức tăng trưởng GDP cao nhất thế giới trong khoảng hơn 30 năm qua, thì trong nhiều năm nay vẫn đang "ngụp lặn" trong giới hạn dưới GDP/người 10.000 USD (PPP 2005). Chắc hẳn những nước này cũng đang toan tính những chiến lược phát triển tương tự như Việt Nam. Vì thế, khả năng Việt Nam vượt qua mức thịnh vượng của nhóm này cũng sẽ là điều không dễ dàng, khôngchắc chắn, chứ chưa nói tới việc vươn lên tiệm cậnmức của nhóm nước Đông Á.Nhóm nước Đông Á không trội hơn so với nhóm nước Đông Nam Á xét về phương diện vị trí địa lý, tài nguyên cũng như mức thịnh vượng tại thời điểm lấy làm năm cơ sở. Vì thế, thành công trong lựa chọn chiến lược phát triển là sự lý giải đúng đắn nhất cho sự khác biệt lớn giữa hai nhóm này. Điều này cũng đưa ra một gợi ý rõ ràng cho Việt Nam là nếu muốn vươn lên trong 20-30 năm tới, việc lựa chọn phương thức phát triển sẽ quyết định việc thực hiện tham vọng quốc gia. Cần phải suy xét một cách nghiêm túc "cách thức Đông Á" và "cách thức Đông Nam Á" khi thực hiện sự lựac chọn này.

\section{b. Việt Nam đứng ở đâu trên các bảng xếp hạng toàn cầu?}

Những chỉ tiêu năng suất lao động, ở một chừng mực nào đó, phản ánh năng suất của một quốc gia, là cái được quyết định bởi sự kết hợp các thể chế, chính sách và các nhân tố sản xuất. Trên không gian toàn cầu, một sự kết hợp như vậy được Diễn đàn Kinh 
tế Thế giới (WEF)tổng quát hóa vào khái niệm năng lực cạnh tranh và từ đó có thể giúp định vị các quốc gia. Theo $\mathrm{WEF}$, có 5 giai đoạn phát triển của các quốc gia trên thế giới, bao gồm: giai đoạn đầu (factor-driven); giai đoạn chuyển đổi (transition); giai đoạn lấy hiệu quả làm động lực (efficiency driven); giai đoạn chuyển đổi lần 2; và giai đoạn lấy sáng tạo làm động lực (innovation driven).

Với cách phân loại này, Việt Nam cho đến 2014 vẫn đang ở giai đoạn đầu, trong khi đó Thái Lan hay Trung Quốc đã ở giai đoạn thứ 3 , Malaysia đã chuyển sang giai đoạn thứ 4. Vì vậy, không có gì ngạc nhiên khi thứ hạng của Việt Nam không có mấy cải thiện, hoặc nếu có thì chỉ là cải thiện trong nội bộ nhóm các nền kinh tế ở giai đoạn đầu của quá trình phát triển. Thậm chí nếu tính từ năm 2010 trở lại đây, Việt Namđang tụt hạng từ vị trí thứ 59 xuống vị trí thứ 68(Hình 11).

Hình 11: Xếp hạng GCI Việt Nam (2006-2014)

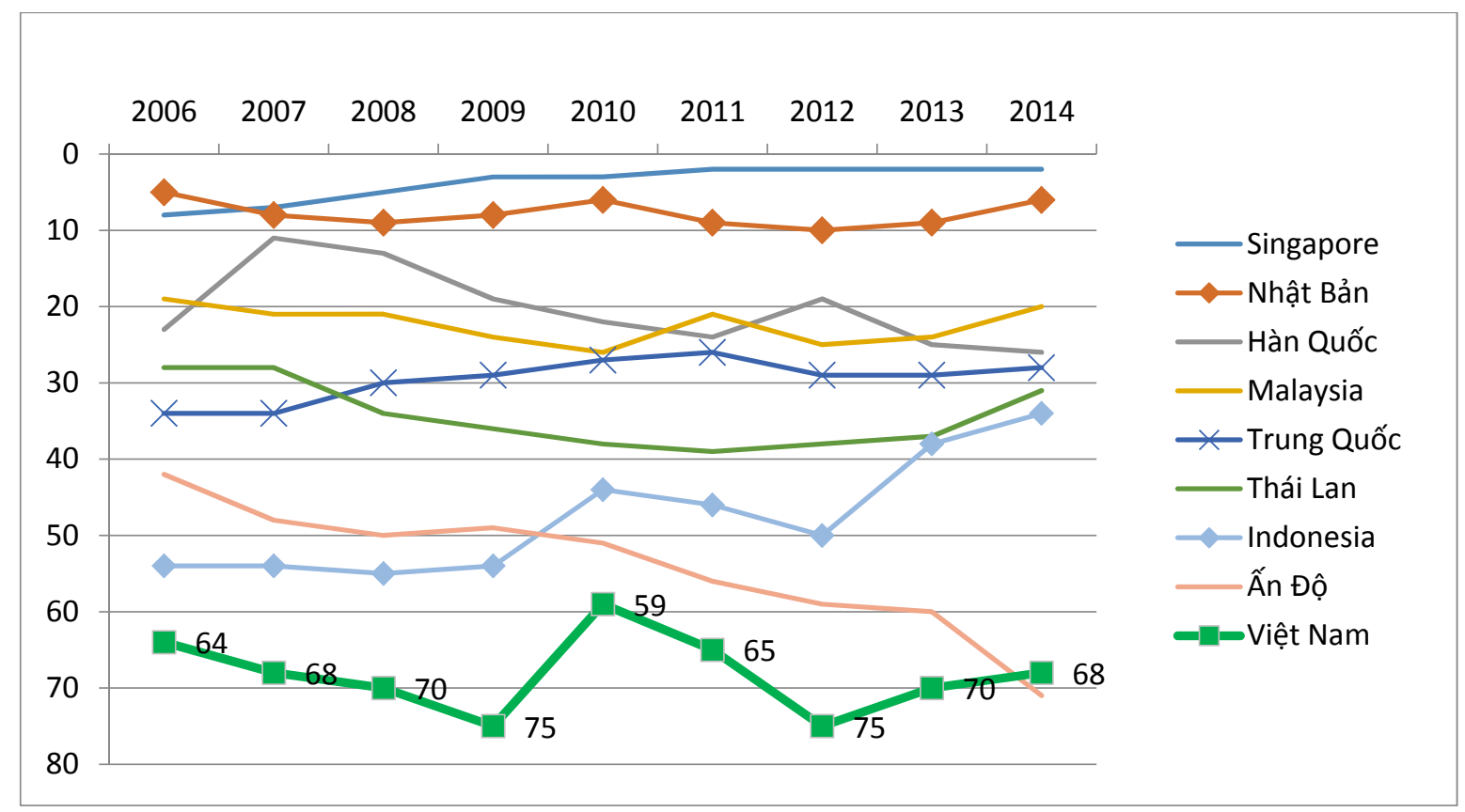

Nguồn: World Economic Forum.

Môi trường thể chế ít được cải thiện hay sự thiếu ổn định của môi trường kinh tế vĩ mô là nguyên do căn bản của thực trạng này. Bên cạnh đó, sự chậm cải thiện về chất lượng nguồn nhân lực và cơ sở vật chất hạ tầng cũng là những nguyên nhân lớn khác.Đây là bốn yếu tố căn bản để thúc đẩy tăng trưởng và chuyển đổi môi hình tăng trưởng, tuy nhiên xếp hạng của Việt Nam cho cả bốn yếu tố này đều đang ở mức thấp và không có nhiều tiến triển trong những năm gần đây.

Việt Nam vẫn xếp ở nửa sau trên bảng xếp hạng toàn cầu cho cả 4 yếu tố vừa nói trên.Trong đó, điểm đánh giá cũng như thứ hạng xếp loại về môi trường thể chế của Việt Nam đều đang nằm trong xu hướng giảm kể từ năm 2009 đến nay (Bảng 8).Điều này hàm ý môi trường thể chế không những không được cải thiện mà lại kém đi.

Yếu tố giáo dục, đào tạo đại diện cho sự cải thiện trong phát triển nguồn nhân lực, gồm đào tạo nghề và đại học, hầu như không có cải thiện suốt từ 2006 đến nay. 
Về cơ sở hạ tầng, sự cải thiện diễn ra khá mạnh trong hai năm trở lại đây, nhưng chủ yếu nhờ vào việc phát triển mạng thông tin di động vốn đã gần như bão hòa.Các thứ hạng về hạ tầng đường bộ, đường biển, đường hàng không có tăng lên, nhưng Việt Nam vẫn thuộc nhóm kém phát triển nhất trong bảng xếp hạng (Bảng 8).

Ngoài 4 yếu tố trên đây, một yếu tố khác không kém phần quan trọng đối với triển vọng tăng trưởng về dài hạn của Việt Nam hiện cũng đứng ở nữa sau của bảng xếp hạng toàn cầu là yếu tố sáng tạo. Điều đáng nói là thứ hạng của Việt Nam đã tụt hạng ở yếu tố này rất nhanh chóng sau năm 2010. Kinh nghiệm Nhật Bản, Hàn Quốc, Singapore hay Đài Loan cho thấy, đổi mới và sáng tạo liên tục là nền tảng tạo nên thành công của nhóm Đông Á. Với thực trạng tính sáng tạo quốc gia của Việt Nam đang đi xuống như vậy, cộng với sự suy giảm của TFP, sự tăng lên của ICOR như đã đề cập cho thấy thực chất tăng trưởng Việt Nam đạt được vẫn chỉ là nhờ vào tăng vốn và lao động thiếu kỹ năng.

\section{Bảng 8: Xếp hạng toàn cầu một số chỉ tiêu của Việt Nam}

\begin{tabular}{|c|c|c|c|c|c|c|c|c|c|c|}
\hline \multicolumn{2}{|c|}{ Báo cáo GCI } & $\begin{array}{c}2006- \\
2007 \\
\end{array}$ & $\begin{array}{c}2007- \\
2008 \\
\end{array}$ & $\begin{array}{c}2008- \\
2009 \\
\end{array}$ & $\begin{array}{c}2009- \\
2010 \\
\end{array}$ & $\begin{array}{c}2010- \\
2011 \\
\end{array}$ & $\begin{array}{l}2011- \\
2012 \\
\end{array}$ & $\begin{array}{c}2012- \\
2013 \\
\end{array}$ & $\begin{array}{c}2013- \\
2014 \\
\end{array}$ & $\begin{array}{l}2014- \\
2015 \\
\end{array}$ \\
\hline \multirow{2}{*}{ Thể chế } & Điểm & 3.62 & 3.78 & 3.87 & 3.93 & 3.80 & 3.63 & 3.61 & 3.54 & 3.51 \\
\hline & Xếp hạng & 71 & 70 & 71 & 63 & 74 & 87 & 89 & 98 & 92 \\
\hline \multirow{2}{*}{$\begin{array}{l}\text { Môi trường } \\
\text { kinh tế vĩ mô }\end{array}$} & Dlem & 5.30 & 5.08 & 4.91 & 3.86 & 4.47 & 4.78 & 4.16 & 4.44 & 4.66 \\
\hline & Xếp hạng & 43 & 51 & 70 & 112 & 85 & 65 & 106 & 87 & 75 \\
\hline \multirow{2}{*}{$\begin{array}{c}\text { Cơ sở hạ } \\
\text { tầng }\end{array}$} & & 2.61 & 2.80 & 2.86 & 3.00 & 3.56 & 3.59 & 3.34 & 3.69 & 3.74 \\
\hline & Xếp hạng & 90 & 89 & 93 & 94 & 83 & 90 & 95 & 82 & 81 \\
\hline \multirow{2}{*}{$\begin{array}{c}\text { Đào tạo và } \\
\text { giáo dục }\end{array}$} & Điểm & 3.31 & 3.39 & 3.36 & 3.54 & 3.64 & 3.47 & 3.69 & 3.69 & 3.74 \\
\hline & Xếp hạn & 89 & 93 & 98 & 92 & 93 & 103 & 96 & 95 & 96 \\
\hline \multirow{2}{*}{$\begin{array}{c}\text { Đổi mới } \\
\text { công nghệ }\end{array}$} & Điểm & 3.17 & 3.22 & 3.35 & 3.45 & 3.40 & 3.16 & 3.07 & 3.14 & 3.12 \\
\hline & Xếp hạng & 62 & 64 & 57 & 44 & 49 & 66 & 81 & 76 & 87 \\
\hline \multicolumn{2}{|c|}{ Số quốc gia xếp hạng } & 125 & 131 & 134 & 133 & 139 & 142 & 144 & 148 & 144 \\
\hline
\end{tabular}

\section{Nguồn: World Economic Forum}

Thành tựu phát triển con người trong lĩnh vực giáo dục cho thấy tiềm năng trí tuệ con người Việt Nam rất to lớn, nhưng Chỉ số năng lực cạnh tranh toàn cầu GCI chỉ ra thêm một căn cứ cho thấy những tiềm năng này chưa có môi trường để chuyển hóa thành lợi thế như cách Nhật Bản, Hàn Quốc hay các nước $\mathrm{OECD}$ đã làm được. Ở đây, một lần nữa cần phải nhắc lại việc lựa chọn chiến lược phát triển. Phát triển kỹ năng cho người lao động là yếu tố tiên quyết để một quốc gia xây dựng và duy trì năng lực cạnh tranh. Việt Nam đã rất nỗ lực và thực tế đã đạt được những thành công lớn về phổ cập giáo dục tiểu học.Tuy nhiên, khi kinh tế thế giới ngày càng trở nên tri thức hóa và kỹ năng hóa, thì phổ cập tiểu học làm được là chưa đủ.Hệ thống giáo dục dựa trên nền tảng thi cử cho cho thấy không phù hợp với các mục tiêu chiến lược về công nghiệp hóa và hiện đại hóa kinh 
tế. Thay vào đó, một hệ thống giáo dục lấy nền tảng thực hành (practice) là điều Việt Nam cần phải cân nhắc triển khai.

Bảng 9: KEI và xếp hạng của Việt Nam (1995-2012)

\begin{tabular}{|l|l|l|l|l|l|}
\hline Năm & $\mathbf{1 9 9 5}$ & $\mathbf{2 0 0 0}$ & $\mathbf{2 0 0 7}$ & $\mathbf{2 0 0 8}$ & $\mathbf{2 0 1 2}$ \\
\hline KEI & 2,61 & 2,72 & 3,1 & 3,02 & 3,4 \\
\hline Xếp hạng & $110 / 140$ & $113 / 142$ & $97 / 137$ & $102 / 134$ & $104 / 145$ \\
\hline
\end{tabular}

Nguồn: Knowledge Economy Index, World Bank

Thứ hạng của Việt Nam trong bảng xếp hạng toàn cầu về Chỉ số Nền kinh tế Tri thức (KEI) củng cố thêm các luận điểm về sự cần thiết phải có những thay đổi về hệ thống giáo dục truyền thống để chuyển hóa những tiềm năng về tri thức của con người thành giá trị thực sự. KEI của Việt Nam có tăng lên, nhưng có thể thấy là mức tăng không đủ lớn để đưa quốc gia vượt lên nửa trên của bảng xếp hạng toàn cầu (Bảng 9).

\section{Hình 12: Xếp hạng toàn cầu chỉ số quản trị công của Việt Nam}

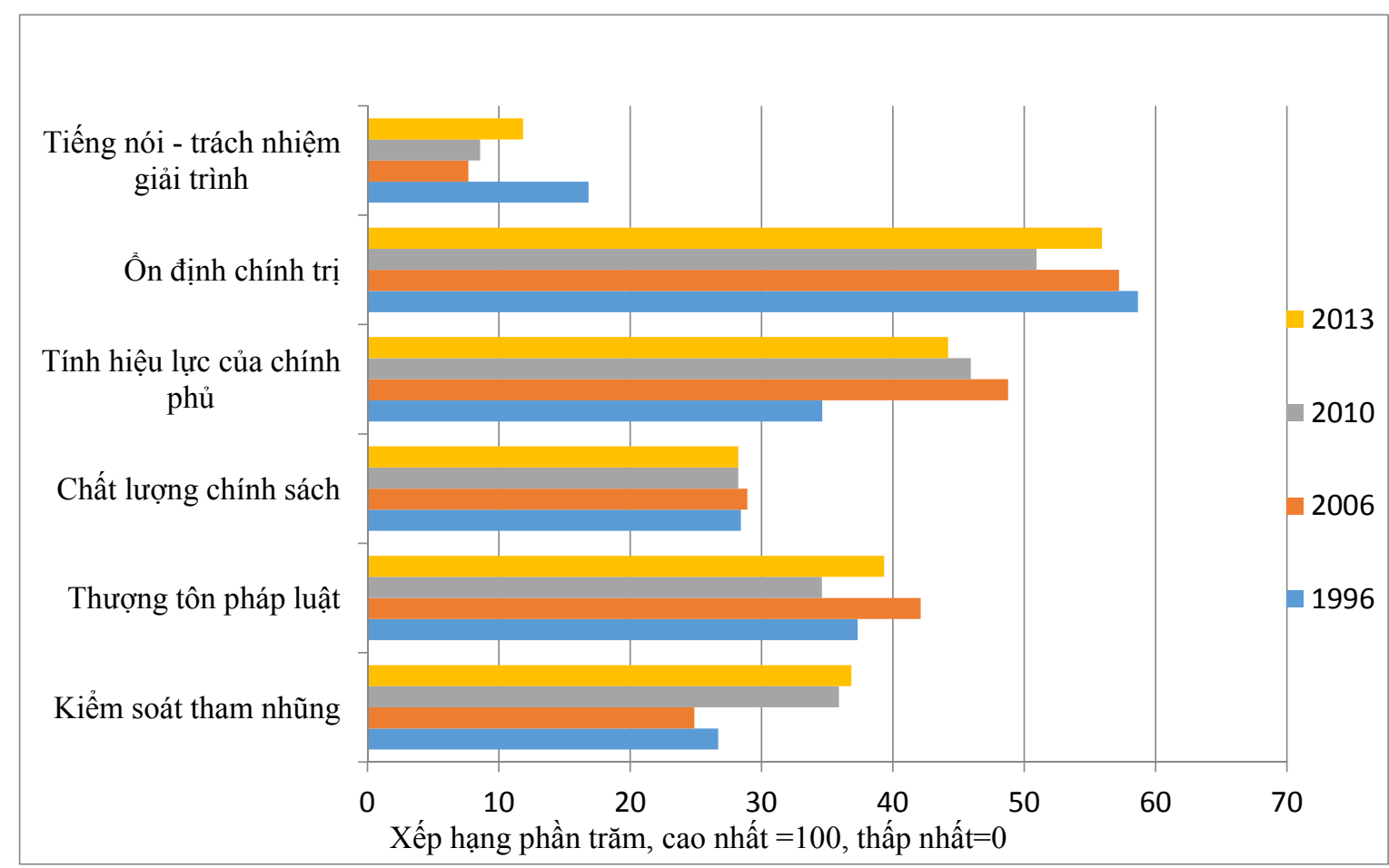

Nguồn: Worldwide Governance, WB.

Sự tương quan rõ rệt giữa GCI và KEI cho thấy để nâng cao năng lực cạnh tranh quốc gia, Việt Nam cần tập trung vào phát triển nền kinh tế tri thức, liên tục đổi mới và tăng tính sáng tạo. Tuy nhiên, có những nút thắt lớn cần giải tỏa để có thể đẩy nhanh tiến trình phát triển nền kinh tế tri thức. Các nỗ lực cải cách thể chế nói chung và thể chế kinh tế nói riêng của Việt Nam trong suốt 30 năm qua chưa tạo ra những yếu tố đột phá. Năng 
lực quản trị của Nhà nước đang là một rào cản lớn.Xếp hạng toàn cầu về Chỉ số Quản trị Công của Việt Nam giai đoạn 1996-2013 cho thấy rõ điều này (Hình 12).

Trong 6 chỉ số đại diện cho các chiều cạnh của quản trị công, Việt Nam chỉ xếp trên vị trí trung vị trong mẫu xếp hạng ở chỉ số ổn định chính trị, là điều hiển nhiên và dễ nhận diện.Còn lại, xếp hạng của 5 chỉ số còn lại cho thấy Việt Nam được xếp vào nhóm $50 \%$ các quốc gia phía dưới của phân phối các chỉ số. Riêng xếp hạng về "Tự do ngôn luận và trách nhiệm giải trình", Việt Nam có xếp hạng rất thấp, chỉ được phân loại vào nhóm $12 \%$ các quốc gia yếu kém nhất.Xếp hạng của chỉ số này có cải thiện từ 2006 đến nay, nhưng vẫn là bước lùi nếu so với chính Việt Nam vào năm 1996. Chất lượng chính sách trong suốt hai thập kỷ vừa qua không có cải thiện nào, trong khi tính hiệu lực của Chính phủ đang giảm xuống sau, còn vấn đề kiểm soát tham nhũng và thượng tôn pháp luật cũng không có nhiều bước tiến vượt. Như thế, hệ thống quản trị nhà nước chưa phát triển theo kịp với xu thế phát triển của thế giới mà Việt Nam lại đang tích cực hội nhập.

Bảng 10: Xếp hạng chất lượng hạ tầng của Việt Nam theo WEF

\begin{tabular}{|l|c|c|c|c|c|c|}
\hline \multicolumn{1}{|c|}{ Năm } & $\mathbf{2 0 0 9}$ & $\mathbf{2 0 1 0}$ & $\mathbf{2 0 1 1}$ & $\mathbf{2 0 1 2}$ & $\mathbf{2 0 1 3}$ & $\mathbf{2 0 1 4}$ \\
\hline Chất lượng hạ tầng nói chung & 97 & 111 & 123 & 123 & 119 & 110 \\
\hline Đường bộ & 102 & 102 & 117 & 123 & 120 & 102 \\
\hline Đường sắt & 66 & 58 & 59 & 71 & 68 & 58 \\
\hline Cảng biền & 112 & 99 & 97 & 111 & 113 & 98 \\
\hline Hàng không & 92 & 103 & 98 & 109 & 113 & 92 \\
\hline Số thuê bao di động/100 dân & & & 58 & 5 & 18 & 21 \\
\hline Số thuê bao cố định/100 dân & 37 & 36 & 35 & 70 & 86 & 88 \\
\hline Số quốc gia được xếp hạng & 133 & 139 & 142 & 144 & 148 & 144 \\
\hline
\end{tabular}

Nguồn: World Economic Indicator

\section{Kết luận}

Chặng đường 30 năm cải cách kinh tế Việt Nam đã chứng kiến những giai đoạn thăng trầm cùng những đột phá trong mở cửa thị trường, giá cả và tiến triển trên đường hội nhập quốc tế.Những thành tựu đáng kể đã được ghi nhận, bao gồm tăng trưởng kinh tế cao nhiều năm liên tục, đưa hàng triệu người thoát khỏi nghèo đói... Tuy nhiên, thế giới luôn vận động theo quy luật đào thải khắc nghiệt. 40 mươi năm sau khi thống nhất đất nước và bước vào giai đoạn xây dựng, phát triển kinh tế, sự phức tạp của kinh tế - chính trị trong khu vực và trên thế giới trong vòng vài năm trở lại đây đang đưa Việt Nam rơi vào một hoàn cảnh mà sự tồn vong của dân tộc ở vào thế hiểm nguy hơn bao hết. Dù có những thành tựu đáng tự hào và đáng ngưỡng mộ trong suốt 3 thập kỷ vừa qua, Việt Nam vẫn đang bị các nước phát triển hơn, đặt biệt là Trung Quốc bỏ lại phía sau và ngày cảng nới rộng khoảng cách. Việt Nam cũng đang bị bỏ lại phía sau các bảng xếp hạng toàn cầu trong phần lớn các tiêu chí phát triển.

Vị thế của Việt Nam chỉ có thể do chính Việt Nam tạo dựng và duy trì. Sự phát triển của kinh tế tư nhân đặt trong nền tảng nền kinh tế với giáo dục kỹ năng chuyên sau, chất lượng thể chế, cơ sở vật chất hạ tầng vượt trội và môi trường kinh tế vĩ mô ổn định 
nên được coi là quan điểm phát triển trong bối cảnh Việt Nam đang cam kết tham gia những cuộc chơi hội nhập đảng cấp cao. Điều không may là Việt Nam đang thiếu tất cả các yếu tố này.Việt Nam đã thành công nhờ đột phá trong cải cách năm 1986. Trước một bối cảnh đầy thách thức, nhưng cũng rất nhiều cơ hội mà thời cuộc hiện đang đặt ra Việt Nam, việc lựa chọn cho mình một chiến lược phát triển đúng đắn trong điều kiện liên tục đổi mới, sáng tạo là đòi hỏi bắt buộc./. 


\section{Tài liệu tham khảo}

1. Albaladejo, M. (2010). Benchmarking Vietnam's Competitive Industrial Performance, Research paper for Vietnam.

2. CIEM (2011). Báo cáo nghiên cứu Năng lực cạnh tranh của doanh nghiệp xuất khẩu trong ba ngành May mặc, Thủy sản và Điện tự ở Việt Nam.

3. Bùi Trinh (2013). Kỷ yếu "Diễn đàn kinh tế mùa thu 2013", tháng 9/2013; trang 297.

4. International Monetary Fund (IMF) (2011). World Economic Outlook Database. Retrieved March25, 2015.

5. Liên Hợp Quốc tại Việt Nam (2014). Thống nhất hành động Báo cáo thường niên năm 2013.

6. Mekong Economics (2013). Inequality, Poverty Reduction and the Middle-Income Trap in Vietnam by Tom Berliner, Do Kim Thanh, Adam McCarty.

7. MPI and Unido (2011). Viet Nam Industrial Competitiveness Report 2011.

8. Nghiep and Quy (1999). Measuring impact of Doi moi on Vietnam's Gross Domestic Product, Asian Economic Journal, 14(3).

9. Nguyen Xuan Thanh and David Dapice (2009). Vietnam's Infrastructure Constraints - Prepared under UNDP - Harvard Policy Dialogue Papers “Series on Vietnam's WTO Accession and International Competitiveness Research", Policy Dialogue Paper Number 3.

10. Ohno K. (2010). Avoiding the Middle Income Trap: Renovating Industrial Policy Formulation in Vietnam, Vietnam Development Forum (VDF), Hanoi.

11. Phạm Minh Chính, Vương Quân Hoàng (2009). Kinh tế Việt Nam: Thăng trầm và đột phá, Nxb. Chính trị Quốc gia.

12. UNDP (2011). Human Development Report.

13. Ủy ban Kinh tế của Quốc hội (2013). Báo cáo Kinh tế Vĩ mô 2013: Thách thức còn ở phía trước.

14. VCCI (2014). Báo cáo Thương niên Doanh nghiệp Việt Nam 2013, Nxb. Thông tin và Truyền Thông.

15. World Bank (2014). Taking stock an update on Vietnam's recent economic development, Hanoi.

16. World Bank (2013). Vietnam Development Report 2014, Skilling up Vietnam:

Preparing the workforce for a modern market economy.

17. World Economic Forum (nhiều năm). Global Competitiveness Report.

\section{Các cơ sở dữ liệu:}

18. ADB database

19. APO Productivity Database.

20. IMF Economic Outlook Database, Octobor 2014.

21. Niên giám Thống kê (Tổng cục Thống kê Việt Nam).

22. Penn World Table 8.0.

23. World Development Indicators (World Bank). 